\title{
VISION Model: Description of Model Used to Estimate the Impact of Highway Vehicle Technologies and Fuels on Energy Use and Carbon Emissions to 2050
}

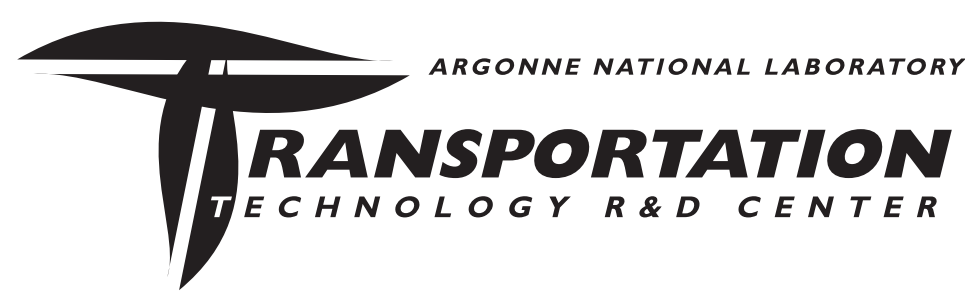

Center for Transportation Research Argonne National Laboratory

Operated by The University of Chicago, under Contract W-31-109-Eng-38, for the United States Department of Energy 
Argonne National Laboratory, a U.S. Department of Energy Office of Science laboratory, is operated by The University of Chicago under contract W-31-109-Eng-38.

\section{DISCLAIMER}

This report was prepared as an account of work sponsored by an agency of the United States Government. Neither the United States Government nor any agency thereof, nor The University of Chicago, nor any of their employees or officers, makes any warranty, express or implied, or assumes any legal liability or responsibility for the accuracy, completeness, or usefulness of any information, apparatus, product, or process disclosed, or represents that its use would not infringe privately owned rights. Reference herein to any specific commercial product, process, or service by trade name, trademark, manufacturer, or otherwise, does not necessarily constitute or imply its endorsement, recommendation, or favoring by the United States Government or any agency thereof. The views and opinions of document authors expressed herein do not necessarily state or reflect those of the United States Government or any agency thereof.

Available electronically at http://www.osti.gov/bridge

Available for a processing fee to U.S. Department of Energy and its contractors, in paper, from:

U.S. Department of Energy

Office of Scientific and Technical Information

P.O. Box 62

Oak Ridge, TN 37831-0062

phone: (865) 576-8401

fax: (865) 576-5728

email: reports@adonis.osti.gov 


\title{
VISION Model: Description of Model Used to Estimate the Impact of Highway Vehicle Technologies and Fuels on Energy Use and Carbon Emissions to 2050
}

\author{
by Margaret Singh \\ Center for Transportation Research \\ Argonne National Laboratory \\ 955 L'Enfant Plaza, SW \\ Washington, D.C. \\ Anant Vyas \\ Center for Transportation Research \\ Argonne National Laboratory \\ 9700 South Cass Avenue \\ Argonne, Illinois 60439 \\ Elyse Steiner* \\ National Renewable Energy Laboratory \\ 910 D Street, SW \\ Washington, D.C.
}

December 2003

Work sponsored by the United States Department of Energy, Assistant Secretary for Energy Efficiency and Renewable Energy, Office of Planning, Budget Formulation and Analysis

\footnotetext{
* Steiner is currently affiliated with the U.S. Environmental Protection Agency, Washington, D.C.
} 


\section{NOTICE}

This technical report is a product of Argonne's Energy Systems Division. For information on the division's scientific and engineering activities, contact:

Director, Energy Systems Division

Argonne National Laboratory

Argonne, Illinois 60439-4815

Telephone (630) 252-3724

Publishing support services were provided by Argonne's Information and Publishing Division (for more information, see IPD's home page: http://www.ipd.anl.gov). 


\section{Contents}

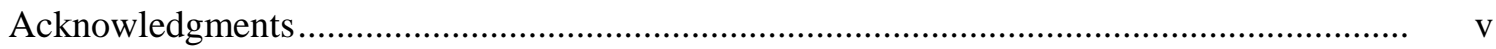

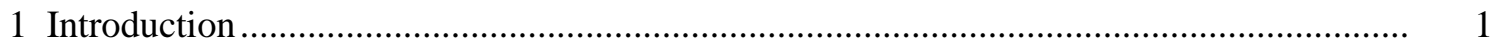

2 Methodology and Input Data: Light Vehicles .................................................................. 5

2.1 Light Vehicle Base Case: VISION 1.1.2 …………………………………………... 5

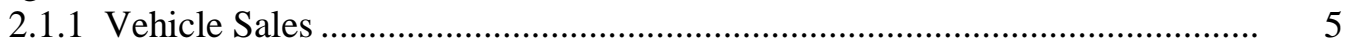

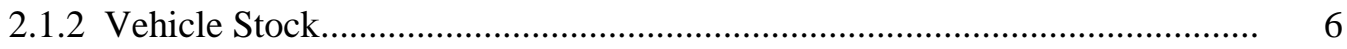

2.1.3 Total Annual VMT and Annual VMT/Vehicle ……………………………..... 6

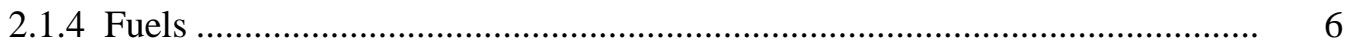

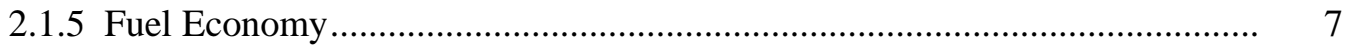

2.1.6 Total Fuel Use ………………………………………………….....

2.1.7 Total Carbon-Equivalent Emissions ……………………………………….... 7

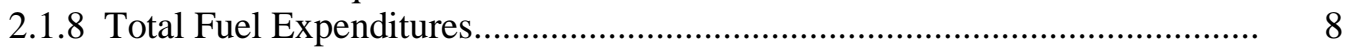

2.2 Light Vehicle Alternative Scenarios: VISION 1.1.2 …………………………….... 8

2.2.1 Higher-Fuel-Economy Conventional Vehicles................................................ 8

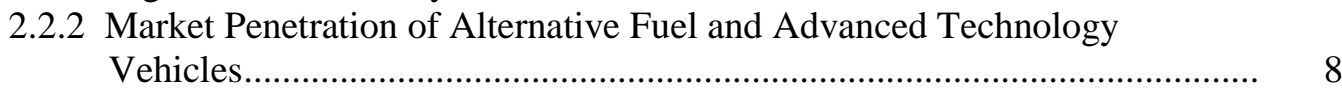

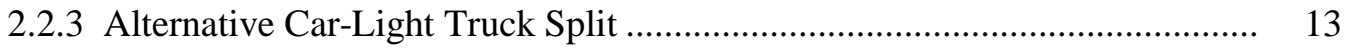

2.2.4 Alternative Fuel Prices ........................................................................... 13

2.2.5 Alternative VMT Estimates and VMT Elasticity Effect ............................... 14

2.2.6 Incremental Vehicle Costs........................................................................ 14

2.3 Light Vehicles in VISION 2.0 ………………………………………………... 14

3 Methodology and Input Data: Heavy Vehicles ............................................................ 17

3.1 Heavy Vehicle Base Case: VISION 1.1.2 …………………………………….. 17

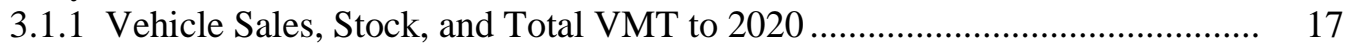

3.1.2 Vehicle Sales, Stock, and Total VMT Post-2020 …………………………... 17

3.1.3 Fuels .......................................................................................... 19

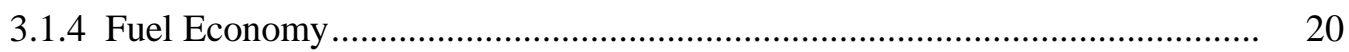

3.1.5 Total Fuel Use by Fuel Type ..................................................................... 20

3.1.6 Total Carbon-Equivalent Emissions ............................................................. 20

3.1.7 Total Fuel Expenditures.............................................................................. 21

3.2 Heavy Vehicle Alternative Scenarios: VISION 1.1.2 …………………………….... 21

3.2.1 Higher-Fuel-Economy Conventional Heavy Vehicles ................................... 21

3.2.2 Market Penetration of Alternative Fuel and Advanced Technology

3.2.3 Alternative Fuel Prices …………………………………………………. 22

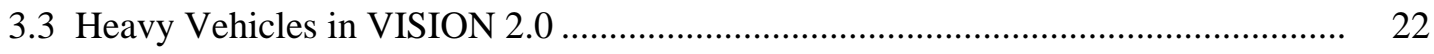




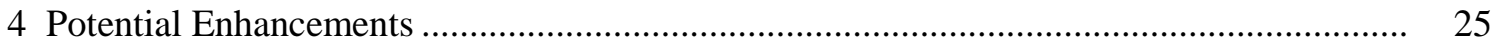

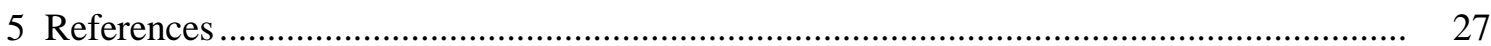

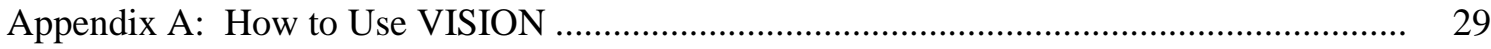

Appendix B: Updating VISION with Data from a New AEO ............................................ 33

\section{Figures}

1.1 Potential Transportation Oil Savings with FCVs ........................................................... 3

1.2 HEV Contribution to Total Light Vehicle Oil Savings from Vehicle-Related Technologies Supported by DOE ..............................................................................

1.3 Lowering 2020 Oil Use to 2000 Level for Clean Cities..................................................... 4

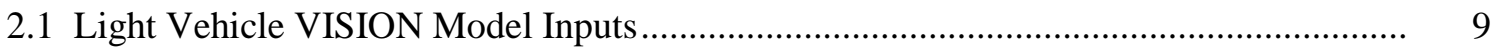

3.1 Heavy and Medium Truck VMT Projections................................................................ 19

3.2 Heavy Vehicle VISION Model inputs …...................................................................... 24

A.1 Sample "Model Results” Sheet ................................................................................... 30

A.2 Sample "Light Vehicle MPG” Sheet ............................................................................ 31

\section{Tables}

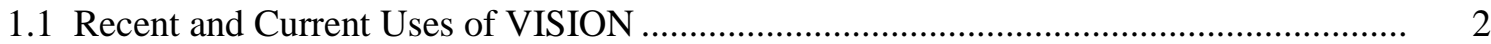

3.1 Heavy Duty Vehicle Sales, Stock, and VMT Estimates in VISION 1.1.2 ...................... 18 


\section{Acknowledgments}

The development of the VISION model has been funded by the Office of Planning, Budget Formulation and Analysis of the Office of Energy Efficiency and Renewable Energy, U.S. Department of Energy. Philip Patterson has been the primary sponsor of the model and its use and we wish to thank him for his extensive support. We would also like to thank the following individuals for their comments on this report's draft: William Key, Oak Ridge National Laboratory; Lew Fulton, International Energy Agency; and John Maples, Energy Information Administration. The authors are solely responsible for the report contents. 
$\Delta$ 


\section{Section 1 Introduction}

The VISION model has been developed by the U.S. Department of Energy (DOE) to provide estimates of the potential energy use, oil use, and carbon emission impacts to 2050 of advanced light- and heavy-duty highway vehicle technologies and alternative fuels. DOE supports research of advanced transportation technologies (including fuels) and is frequently asked to provide estimates of the potential impacts of successful market penetration of these technologies, sometimes on a relatively quick-turnaround basis.

VISION is a spreadsheet model in Microsoft Excel that can be used to respond rapidly to quick-turnaround requests, as well as for longer-term analyses. It uses vehicle survival and agedependent usage characteristics to project total light and heavy vehicle stock, total vehicle miles of travel (VMT), and total energy use by technology and fuel type by year, given market penetration and vehicle energy efficiency assumptions developed exogenously. Total carbon emissions for on-highway vehicles by year are also estimated because life-cycle carbon coefficients for various fuels are included in VISION.

VISION is not a substitute for the transportation component of the Energy Information Administration's (EIA's) National Energy Modeling System (NEMS). NEMS incorporates a consumer choice model to project market penetration of advanced vehicles and alternative fuels. The projections are made within the context of the entire U.S. economy. However, the NEMS model is difficult to use on a quick-turnaround basis and only makes projections to 2025 . VISION complements NEMS with its relative "user-friendliness" and by extending the time frame of potential analysis.

VISION has been used for a wide variety of purposes. For illustration, we have listed some of its most recent and current uses in Table 1.1. Figures 1.1-1.3 illustrate the results of some of those runs. These graphs are not actual model output, but they are based on model results.

The main body of this report describes VISION's methodology and data sources. The methodology and data sources used in the light- and heavy-vehicle portions of the model are discussed separately. Some suggestions for future improvements to the model are made. Appendix A provides instructions on how to run the VISION model. Appendix B describes the procedure for updating the model with the latest EIA Annual Energy Outlook (AEO). 
Table 1.1 Recent and Current Uses of VISION

\begin{tabular}{|c|c|c|}
\hline Requestor & Use & $\begin{array}{l}\text { Sample } \\
\text { Figures }\end{array}$ \\
\hline $\begin{array}{l}\text { DOE Office of Energy Efficiency and } \\
\text { Renewable Energy (DOE EERE)/ } \\
\text { Office of Hydrogen, Fuel Cells \& } \\
\text { Infrastructure Technologies Program }\end{array}$ & $\begin{array}{l}\text { Impact of proposed FreedomCAR and Fuel Initiative } \\
\text { (potential impact of fuel cell vehicles [FCVs] used in Fuel Cell } \\
\text { Report to Congress and draft Multi-Year Research, } \\
\text { Development and Demonstration Plan) } \\
\text { FCV market penetration scenario for draft Posture Plan }\end{array}$ & 1.1 \\
\hline $\begin{array}{l}\text { DOE EERE/Office of FreedomCAR } \\
\text { and Vehicle Technologies Program }\end{array}$ & $\begin{array}{l}\text { Oil reduction target for hybrid electric vehicles (HEVs) in draft } \\
\text { research plan } \\
\text { Staff paper on potential contribution of gasoline HEVs to oil } \\
\text { reduction } \\
\text { Respond to Congressional questions on light-duty diesels }\end{array}$ & 1.2 \\
\hline $\begin{array}{l}\text { DOE EERE/Office of Weatherization } \\
\text { and Intergovernmental Program }\end{array}$ & $\begin{array}{l}\text { Evaluation of how increased alternative fuel use and light- } \\
\text { duty vehicle (LDV) fuel economy could be combined to reach } \\
\text { a particular oil savings goal in } 2020\end{array}$ & 1.3 \\
\hline DOE EERE/Board of Directors & $\begin{array}{l}\text { Impact of various forms of rebates and feebates on oil use } \\
\text { and associated government expenditures through } 2020 \\
\text { (another model was first used to estimate the ultimate new- } \\
\text { vehicle miles-per-gallon [MPG] achieved and government } \\
\text { expenditures for specific programs) }\end{array}$ & \\
\hline $\begin{array}{l}\text { DOE Office of Policy and } \\
\text { International Affairs }\end{array}$ & $\begin{array}{l}\text { Demand estimates for DOE's study of Premium Diesel Fuel } \\
\text { Availability Issues }\end{array}$ & \\
\hline $\begin{array}{l}\text { Department of Transportation/ } \\
\text { National Highway Transportation } \\
\text { Safety Administration (DOT/NHTSA) }\end{array}$ & $\begin{array}{l}\text { Answer question on how to reduce LDV fuel use by } 5 \% \text { in } \\
2010 \text { (proposed Congressional legislative amendment) } \\
\text { Estimate the LDV MPG that would be required to save } \\
1 \text { million barrels per day (mbpd) by } 2015\end{array}$ & \\
\hline Congressional Budget Office & $\begin{array}{l}\text { Estimate the LDV MPG that would be required to save } \\
1 \mathrm{mbpd} \text { by } 2015 \text { (different assumptions than for DOT/NHTSA) }\end{array}$ & \\
\hline Private Industry & $\begin{array}{l}\text { Estimate impact of various LDV greenhouse gas emission } \\
\text { reduction strategies (higher vehicle fuel economy standards } \\
\text { and gasoline tax) }\end{array}$ & \\
\hline
\end{tabular}




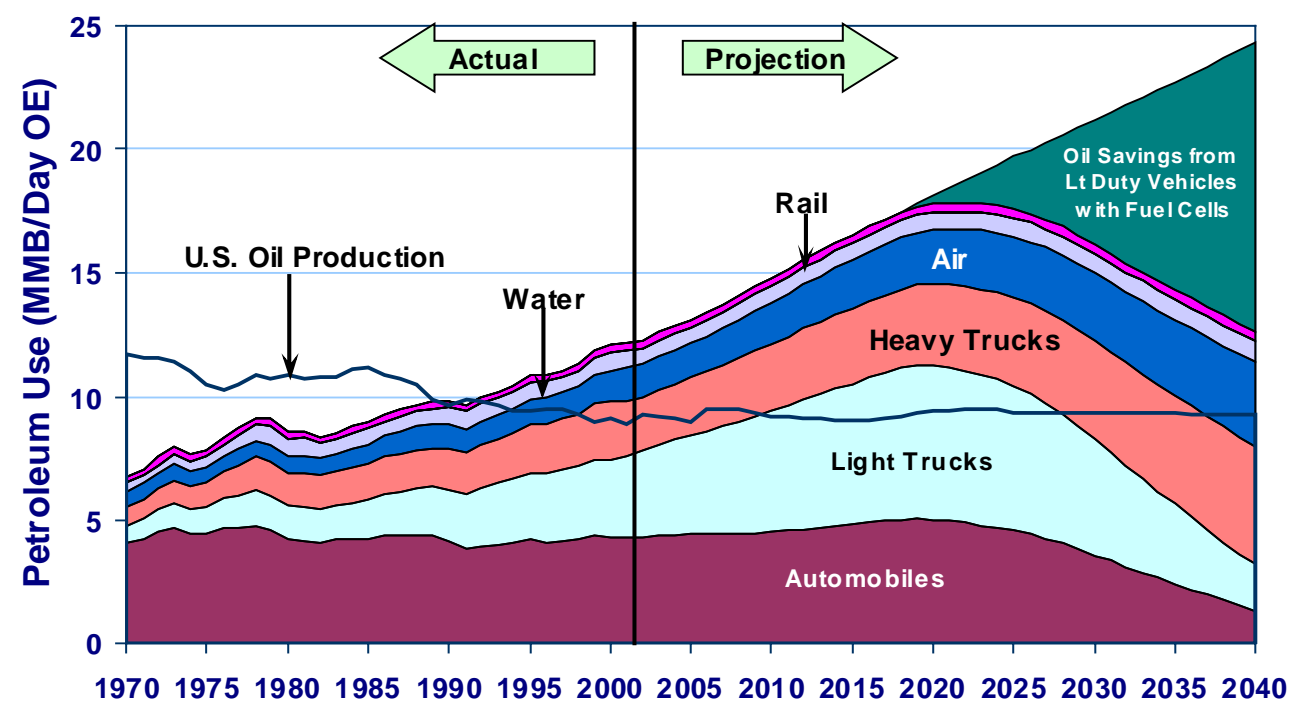

Figure 1.1 Potential Transportation Oil Savings with FCVs (December 2002)

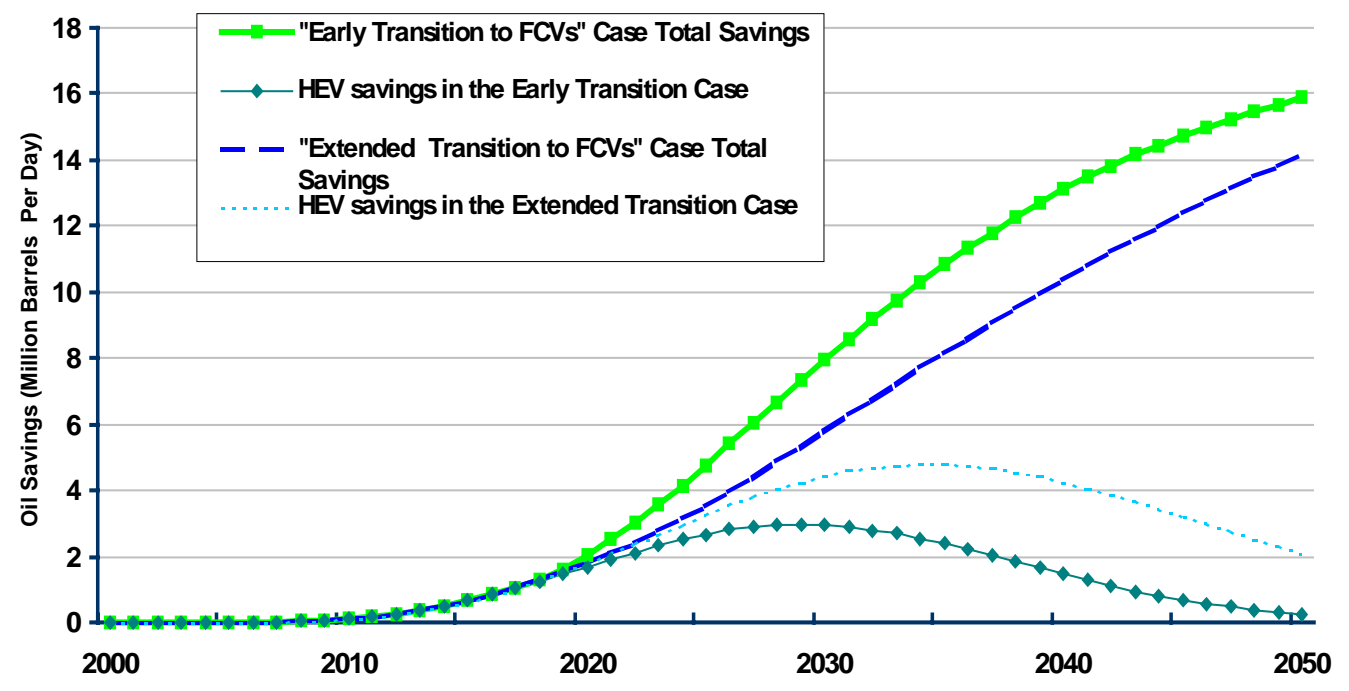

Figure 1.2 HEV Contribution to Total Light Vehicle Oil Savings from Vehicle-Related Technologies Supported by DOE (June 2003) 


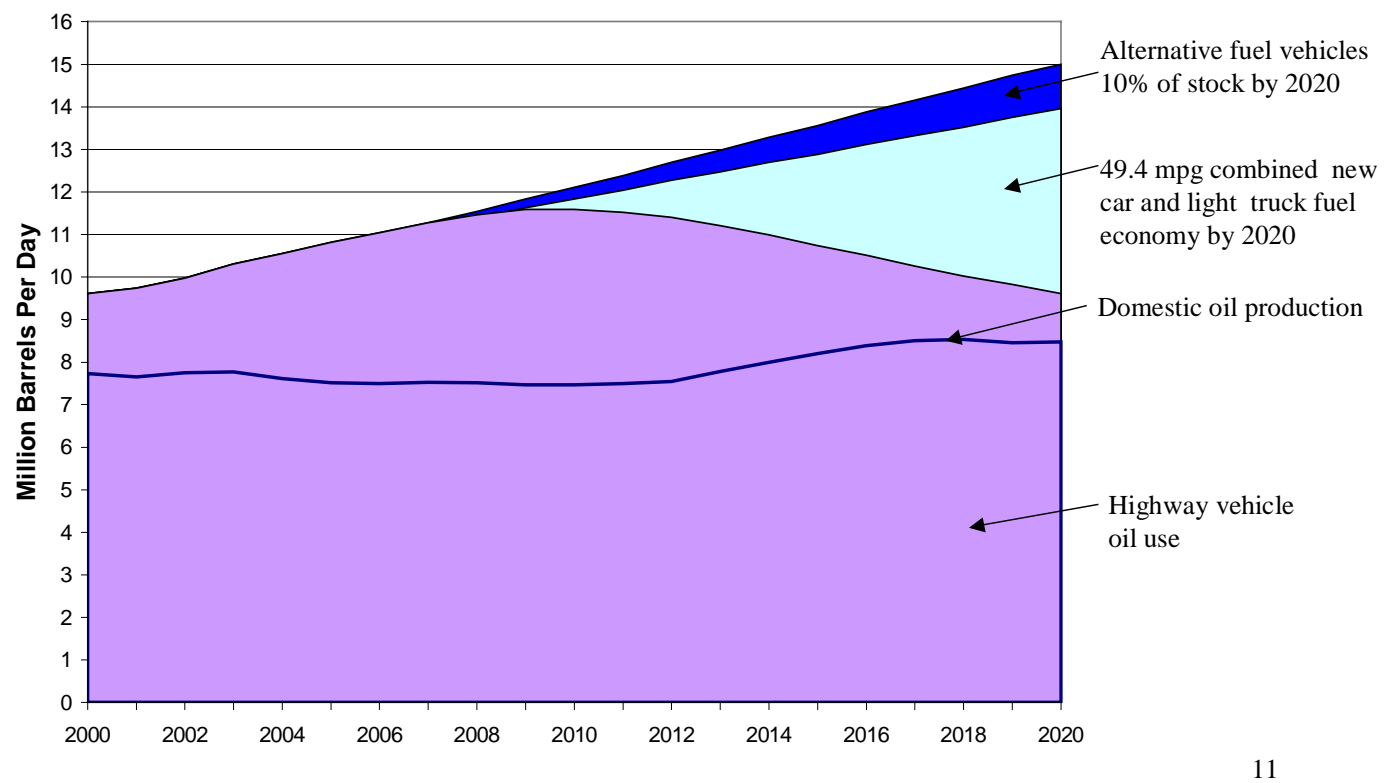

Figure 1.3 Lowering 2020 Oil Use to 2000 Level for Clean Cities (July 2002) 


\section{Section 2 Methodology and Input Data: Light Vehicles}

VISION contains a Base Case projection of U.S. highway transportation energy use to 2050. As much as possible, it relies on EIA AEO projections, but there are some key differences thus, the Base Case does not match the EIA forecast. This section of the report explains the derivation of the Base Case projection for light vehicles and how it can be modified in the model to evaluate alternative assumptions about the market penetration of advanced technologies, alternative fuels, and fuel economy

There are now two versions of the model: VISION 1.1.2, which uses AEO 2002 projections to 2020, and VISION 2.0, which is an update of VISION 1.1.2 and uses AEO 2003 projections to $2025(1,2)$. The VISION model became available for public use in the spring of 2002 as VISION 1.0. There have been several minor modifications to it since that time. The methodology for VISION 1.1.2 is explained first since it has been used extensively. Key changes made to the methodology for VISION 2.0 are then described briefly.

\subsection{Light Vehicle Base Case: VISION 1.1.2}

Light vehicle (car and light truck) energy and oil use and carbon emissions are determined by the total number of vehicles in operation, the total number of miles they travel, their energy efficiency, and the fuels they use. The derivation of these estimates is explained below.

\subsubsection{Vehicle Sales}

Historical sales of cars and light trucks to 2000 are derived from the Transportation Energy Data Book and Ward's Motor Vehicle Facts and Figures $(3,4)$. Total light vehicle $(\mathrm{LV})$ sales to 2020 are taken from the AEO 2002. EIA presents separate sales estimates of cars and light trucks, which it calls light-duty vehicles, and of commercial light trucks, which are classified as Class $2 \mathrm{~b}$ light trucks $(8,500-10,000 \mathrm{lb}$ GVW [gross vehicle weight]). In VISION, the Class $2 \mathrm{~b}$ light trucks are added to the estimate of cars and other light trucks to develop a total LV sales estimate.

Total LV sales post-2020 assume that the per-capita LV sales rate of 2020 calculated in VISION applies to all years in the future. Population estimates to 2050 are taken directly from the U.S. Census Bureau (5).

VISION does not use EIA's estimates of the car-light truck sales split of the total LV market. Instead, VISION's Base Case assumes that beginning in 2001, the car-light truck split will be 50-50. This split extends to 2050. The model also contains EIA's estimates of the car-light truck sales split in the event the user wishes to use those estimates. In the AEO 2002, EIA

\footnotetext{
${ }^{1}$ Also referred to as light-duty vehicle, or LDV.
} 
estimates that the light truck share of LV sales will rise from $48 \%$ in 2001 to $51.9 \%$ in 2020 . This share is extrapolated to $52 \%$ in 2030 and held constant after that.

EIA projects limited market penetration of diesel vehicles, as well as alternative fuel and advanced technology vehicles (electric vehicles [EVs], compressed natural gas [CNG], E-85 [85\% ethanol], hybrids, and fuel cell vehicles). However, the VISION Base Case assumes no such penetration, because many analysts want to evaluate the effects of new technology penetration relative to the dominant current technology. Thus, all light vehicles are assumed to be conventional internal combustion engine vehicles $(\mathrm{CVs})$ running on gasoline.

\subsubsection{Vehicle Stock}

Historical car and light truck stock before 1990 are taken from the Transportation Energy Data Book. Annual car and light truck stock from 1990 to 2050 are estimated by using a vehicle stock model. The form of that model is described elsewhere in the IMPACTT5A report (6). Essentially, historical vehicle survival rates are applied to develop a preliminary estimate of vehicle stock in any year (14). (Survival rates for cars and light trucks differ slightly.) Correction factors are applied to the stock and are thus estimated to match historical registration data (7) and AEO 2002 projections of total vehicle stock to 2020. For years post-2020, the preliminary estimate is then adjusted to ensure consistency with the vehicle/VMT estimates calculated elsewhere and discussed below.

Although there are some diesel vehicles and alternative fuel and advanced technology vehicles in operation today, the Base Case does not account for them or their survival in the future. Implicitly, these vehicles are included in the gasoline car and light truck stock estimates of the Base Case.

\subsubsection{Total Annual VMT and Annual VMT/Vehicle}

VISION uses EIA's estimates of VMT growth rates for cars and light trucks to 2020, but it applies them to the Federal Highway Administration's (FHWA's) estimate of total VMT in 2000 rather than EIA's (7). This value provides the total VMT estimates used in VISION to 2020. It also provides annual VMT/vehicle estimates through 2020 (e.g., 14,515 mi/yr for cars and $13,230 \mathrm{mi} / \mathrm{yr}$ for light trucks in 2020).

Post-2020, VISION assumes a gradual decline in total VMT growth: from $1.3 \% / y r$ for cars in 2020 to $0.8 \%$ by 2050 and from $1.9 \%$ for light trucks in 2020 to $0.8 \%$ by 2050 . The specific annual growth rates are model inputs. At the same time, VISION assumes a gradual increase in annual VMT/vehicle by cars and light trucks to $15,000 \mathrm{mi} / \mathrm{yr}$ by 2050 for each vehicle type. The total VMT for any projection year represents the product of vehicle stock and annual VMT/vehicle. Correction factors are applied to the first-cut total stock estimates described above to ensure a gradual increase to the desired total VMT end point.

\subsubsection{Fuels}

As indicated above, all the vehicles in the Base Case are gasoline-fueled. The gasoline is assumed to contain no ethanol blends. 


\subsubsection{Fuel Economy}

The fuel economy of new gasoline-fueled vehicles is held constant from 2000 to 2050 . The certification test fuel economy values are 28.5 MPG for cars and 21.2 MPG for light trucks. (These values represent the car and light truck Corporate Average Fuel Economy [CAFE] achieved by model year 2000 cars and light trucks.) The assumption of constant fuel economy differs from EIA's projections of slight improvements in the fuel economy of gasoline-fueled CVs. VISION uses a fixed MPG Base Case because many analyses want to evaluate the effects of new technology penetration relative to existing technology. However, use of the fixed MPG Base Case does mean that analysts assuming some percentage improvement in fuel economy over time will estimate larger impacts than if the EIA Reference Case was used as the base case.

On-road vehicle fuel economy is lower. It is estimated to be $80 \%$ of the certification test fuel economy values (e.g., see reference 15). It is assumed that this percentage will not change over time.

VISION calculates average fleet fuel economy for each year. It uses historical values for VMT use by vehicle age, vehicle stock by age by calendar year, and on-road vehicle fuel economy by calendar year to generate these estimates. The initial estimate that VISION generates for 2000 is matched to the FHWA estimate for that year by applying a correction factor. That correction factor is applied throughout the 2001-2050 period.

\subsubsection{Total Fuel Use}

Total fuel use for any year is computed as total VMT divided by fleet fuel economy. Again, the initial estimate that VISION generates for 2000 is matched to the FHWA estimate for that year by applying a correction factor. That correction factor is applied throughout the 2001-2050 period. Total fuel use in gallons is converted to Quads, assuming the higher heating value of gasoline $(125,000 \mathrm{Btu} / \mathrm{gal})$.

\subsubsection{Total Carbon-Equivalent Emissions}

Total carbon-equivalent emissions are estimated by using a carbon coefficient per unit of fuel consumed. The carbon coefficient represents full fuel-cycle emissions associated with fuel use (i.e., it includes carbon emissions from petroleum production through emissions at the refinery to delivery to and use of the fuels in the vehicles). Thus, the carbon-equivalent emissions estimates cover more phases of the fuel cycle than are captured in the vehicle energy use estimates developed with VISION. The source of these carbon coefficients is the GREET model (8). The coefficients account for the global warming potential of carbon dioxide, methane, and nitrous oxide.

In the VISION Base Case, only gasoline is used. Its carbon coefficient is invariant across years: 22.54 MMTCe/quad. The baseline gasoline contains no blends. 


\subsubsection{Total Fuel Expenditures}

VISION includes fuel price per gallon estimates for gasoline (including taxes). AEO 2002 is the source of the estimates to 2020. Post-2020, it is assumed that the real price of gasoline will rise to $\$ 2.10 /$ gal by 2050 . Given these price assumptions and total fuel use estimates, VISION calculates annual total fuel expenditures.

\subsection{Light Vehicle Alternative Scenarios: VISION 1.1.2}

Figure 2.1 presents the variables in VISION that can easily be modified to create alternative scenarios of light-vehicle energy use. The figure is a copy of the light vehicle portion of the VISION Model Input sheet. Market penetration of electric, ethanol, diesel, natural gas, hybrid electric, fuel cell, and higher-fuel-economy conventional vehicles (both cars and light trucks) can be simulated.

The fuel economy of all these vehicle types can be varied. The light truck share of new LV sales can be changed. The hybrid and fuel cell vehicles may use any one of several fuels. The share of ethanol in gasoline, the share of Fischer-Tropsch (F-T) diesel used in diesel fuel production, and the share of renewables used to produce hydrogen can be varied. The LV VMT may be changed at predetermined growth rates or be elastic to fuel cost per mile. The following discussion describes how a user of the VISION model can change these variables and others to create alternative scenarios of fuel use and vehicle technologies.

Besides changing the variables shown in Figure 2.1, other inputs are sometimes hard-wired into VISION runs. For example, VISION uses linear interpolation for market penetration estimates (see Section 2.2.2). Alternative assumptions (i.e., S-curves) may be hard-wired into the model for specific runs. We do not discuss such modifications in this section.

\subsubsection{Higher-Fuel-Economy Conventional Vehicles (gasoline-fueled)}

Changing the $\mathrm{CV}$ fuel economy in future years is the simplest alternative case. Given a start date and the ratio of the fuel economy of the higher-fuel-economy CVs to the fuel economy of the Base Case CVs, the model generates an average fleet fuel economy and thus total fuel use as an alternative to those in the Base Case.

\subsubsection{Market Penetration of Alternative Fuel and Advanced Technology Vehicles (including diesels)}

Given a start date and percentage of new alternative fuel and advanced technology vehicles sold in 2010, 2020, 2030, 2040, and 2050, the model generates estimates of the percentage of sales of these vehicles in all years by using linear interpolation for the intervening years. The model then generates estimates of alternative fuel and advanced technology total vehicle sales, stock, and VMT by using the same methods as those described for the Base Case. These estimates are then subtracted from the total vehicle sales, stock, and VMT estimates of the Base Case to estimate the modified conventional vehicle sales, stock, and VMT for the scenario. 
LIGHT VEHICLE ASSUMPTIONS

Auto (Car) Market Penetration

Enter each technology's share of new vehicies manket

MUST specify "1st Year" and "1st Yr Shr"for the technology for which either manket share or fuel economv change is desired.

\begin{tabular}{|l|cccccc|c|c|}
\hline Technology & 2000 & 2010 & 2020 & 2030 & 2040 & 2050 & 1st Year & 1st Yr Shr \\
\hline
\end{tabular}

\begin{tabular}{l|rrrrrr|r|r|}
\hline Technology & \multicolumn{1}{c}{ 200 } & $\mathbf{2 0 1 0}$ & $\mathbf{2 0 2 0}$ & $\mathbf{2 0 3 0}$ & $\mathbf{2 0}$ & $\mathbf{2 0 5 0}$ & 1st Year & 1st Yr Shr \\
E-85 & $0.0 \%$ & $0.0 \%$ & $0.0 \%$ & $0.0 \%$ & $0.0 \%$ & $0.0 \%$ & 0 & $0.0 \%$ \\
Diesel & $0.0 \%$ & $0.0 \%$ & $0.0 \%$ & $0.0 \%$ & $0.0 \%$ & $0.0 \%$ & 0 & $0.0 \%$ \\
CNG & $0.0 \%$ & $0.0 \%$ & $0.0 \%$ & $0.0 \%$ & $0.0 \%$ & $0.0 \%$ & 0 & $0.0 \%$ \\
HEV & $0.0 \%$ & $0.0 \%$ & $0.0 \%$ & $0.0 \%$ & $0.0 \%$ & $0.0 \%$ & 0 & $0.0 \%$ \\
Fuel Cell & $0.0 \%$ & $0.0 \%$ & $0.0 \%$ & $0.0 \%$ & $0.0 \%$ & $0.0 \%$ & 0 & $0.0 \%$ \\
\hline Conventional & $0.0 \%$ & $0.0 \%$ & $0.0 \%$ & $0.0 \%$ & $0.0 \%$ & $0.0 \%$ & 0 & $0.0 \%$ \\
\hline
\end{tabular}

\begin{tabular}{lllllll}
\hline TOTAL & $100.0 \%$ & $100.0 \%$ & $100.0 \%$ & $100.0 \%$ & $100.0 \%$ & $100.0 \%$
\end{tabular}

New Auto Fuel Economy Ratio to Base ICE (using gasoline equivalent gallons)

Enter a ratio to Base ICE mpg (isted in the top row)

if a fuel economy change is desired, specify the first year fuel economy (i.e. mpg) in column i.

For Reference Case Fuel Efficiency, enter " 1 "under "Use Ref. Case MPG"

Enter "0"under "Use Ref. Case MPG" to change Fuel Efficiency Ratio

\begin{tabular}{|c|c|c|c|c|c|c|c|c|}
\hline & 2000 & 2010 & 2020 & 2030 & 2040 & 2050 & \multirow{2}{*}{$\begin{array}{c}\text { Use Ref } \\
\text { Case MPG }\end{array}$} & \multirow{2}{*}{$\begin{array}{l}\text { MPG in } \\
1 \text { st Year }\end{array}$} \\
\hline Base ICE & 28.50 & 28.50 & 28.50 & 28.50 & 28.50 & 28.50 & & \\
\hline$E V(1)$ & 1.00 & 1.59 & 1.56 & 1.56 & 1.56 & 1.56 & 1 & 0.00 \\
\hline$E-85$ & 1.00 & 1.05 & 1.11 & 1.11 & 1.11 & 1.11 & 1 & 0.00 \\
\hline Diesel & 1.36 & 1.39 & 1.44 & 1.44 & 1.44 & 1.44 & 1 & 0.00 \\
\hline CNG & 1.03 & 1.07 & 1.11 & 1.11 & 1.11 & 1.11 & 1 & 0.00 \\
\hline HEV & 1.36 & 1.33 & 1.32 & 1.32 & 1.32 & 1.32 & 1 & 0.00 \\
\hline Fuel Cell & 1.80 & 1.75 & 1.70 & 1.70 & 1.70 & 1.70 & 1 & 0.00 \\
\hline Conventional & 1.00 & 1.00 & 1.00 & 1.00 & 1.00 & 1.00 & 1 & 0.00 \\
\hline
\end{tabular}

Conventional 1 include transmission and distribution losses in the mpg ratio

Linht Truck Market Penetration

Enter each technology's share of new vehicies manket

MUST specify "Ist Year" and "1st Yr Shr"for the technology for which either maket share or fuel economy change is desired. Technology

\begin{tabular}{l|rrrrrr|r|r|} 
Technology & \multicolumn{1}{l}{$\mathbf{2 0 0 0}$} & $\mathbf{2 0 1 0}$ & $\mathbf{2 0 2 0}$ & $\mathbf{2 0 3 0}$ & $\mathbf{2 0 4 0}$ & $\mathbf{2 0 5 0}$ & 1st Year & 1st Yr Shr \\
\hline EV & $0.0 \%$ & $0.0 \%$ & $0.0 \%$ & $0.0 \%$ & $0.0 \%$ & $0.0 \%$ & 0 & $0.0 \%$ \\
E-85 & $0.0 \%$ & $0.0 \%$ & $0.0 \%$ & $0.0 \%$ & $0.0 \%$ & $0.0 \%$ & 0 & $0.0 \%$ \\
Diesel & $0.0 \%$ & $0.0 \%$ & $0.0 \%$ & $0.0 \%$ & $0.0 \%$ & $0.0 \%$ & 0 & $0.0 \%$ \\
CNG & $0.0 \%$ & $0.0 \%$ & $0.0 \%$ & $0.0 \%$ & $0.0 \%$ & $0.0 \%$ & 0 & $0.0 \%$ \\
HEV & $0.0 \%$ & $0.0 \%$ & $0.0 \%$ & $0.0 \%$ & $0.0 \%$ & $0.0 \%$ & 0 & $0.0 \%$ \\
Fuel Cell & $0.0 \%$ & $0.0 \%$ & $0.0 \%$ & $0.0 \%$ & $0.0 \%$ & $0.0 \%$ & 0 & $0.0 \%$ \\
\hline Conventional & $100.0 \%$ & $100.0 \%$ & $100.0 \%$ & $100.0 \%$ & $100.0 \%$ & $100.0 \%$ & 0 & $0.0 \%$ \\
\hline
\end{tabular}

\begin{tabular}{lllllll}
\hline TOTAL & $100.0 \%$ & $100.0 \%$ & $100.0 \%$ & $100.0 \%$ & $100.0 \%$ & $100.0 \%$
\end{tabular}

Linht Truck Share of Total LDV Market

To change light truck share of total LDV, speafy "Yes" in column A and new shares in B through G.

if a light truck share of LDV market change is desired, MUST specify "1st Year" and "1st Yr Shr."

\begin{tabular}{|l|l}
\hline Change Lt & Light Tru ck Share of Total LDV Market
\end{tabular}

\begin{tabular}{|c|cccccc|c|r|}
\hline \multirow{2}{*}{ Truck Share? } & $\mathbf{2 0 0 0}$ & $\mathbf{2 0 1 0}$ & $\mathbf{2 0 2 0}$ & $\mathbf{2 0 3 0}$ & $\mathbf{2 0 4 0}$ & $\mathbf{2 0 5 0}$ & 1st Year & 1st Yr Shr \\
\hline Yes & $49.0 \%$ & $50.0 \%$ & $50.0 \%$ & $50.0 \%$ & $50.0 \%$ & $50.0 \%$ & 2001 & $50.0 \%$ \\
\hline
\end{tabular}

New LiahtInuckFuelEconomvBatio to Base_CE (usina aasoline enuivalentaallons)

Enter a ratio to Base lCE mpg (isted in the top row).

if a fuel economy change is desired, specify the first year fuel economy (i.e. mpg) in column!

For Reference Case Fuel Efficiency, enter " 1 "under "Use Ref. Case MPG"

Enter "0"under "Use Ref. Case MPG" to change Fuel Efficiency Ratio

\begin{tabular}{l|cccccc|c|c|}
\cline { 2 - 8 } & $\mathbf{2 0 0 0}$ & $\mathbf{2 0 1 0}$ & $\mathbf{2 0 2 0}$ & $\mathbf{2 0 3 0}$ & $\mathbf{2 0 4 0}$ & $\mathbf{2 0 5 0}$ & $\begin{array}{c}\text { Use Ref } \\
\text { Case MPG }\end{array}$ & $\begin{array}{c}\text { M in } \\
\mathbf{1} \text { Year }\end{array}$ \\
\hline Base ICE & $\mathbf{2 1 2 0}$ & $\mathbf{2 1 . 2 0}$ & $\mathbf{2 1 . 2 0}$ & $\mathbf{2 1 . 2 0}$ & $\mathbf{2 1 . 2 0}$ & $\mathbf{2 1 . 2 0}$ & Case \\
\hline EV (1) & 1.02 & 1.64 & 1.63 & 1.63 & 1.63 & 1.63 & $\mathbf{1}$ & 0.00 \\
E-85 & 1.09 & 1.14 & 1.20 & 1.20 & 1.20 & 1.20 & $\mathbf{1}$ & 0.00 \\
Diesel & 1.33 & 1.36 & 1.42 & 1.42 & 1.42 & 1.42 & $\mathbf{1}$ & 0.00 \\
CNG & 1.04 & 1.09 & 1.14 & 1.14 & 1.14 & 1.14 & $\mathbf{1}$ & 0.00 \\
HEV & 1.44 & 1.39 & 1.37 & 1.37 & 1.37 & 1.37 & $\mathbf{1}$ & 0.00 \\
Fuel Cell & 2.07 & 1.92 & 1.77 & 1.77 & 1.77 & 1.77 & $\mathbf{1}$ & 0.00 \\
Conventional & 1.00 & 1.00 & 1.00 & 1.00 & 1.00 & 1.00 & $\mathbf{1}$ & 0.00 \\
\hline
\end{tabular}

1) include transmission and distribution losses in the mpg ratio

Figure 2.1 Light Vehicle VISION Model Inputs 


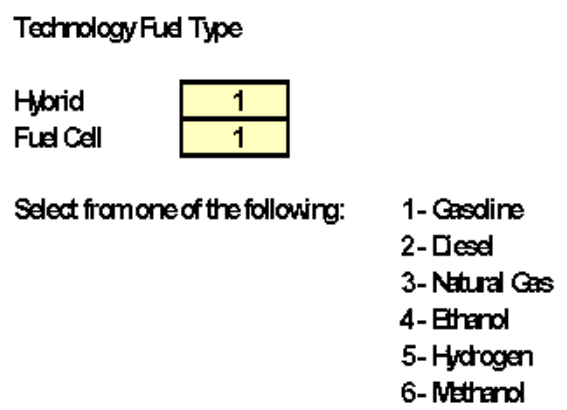

\begin{tabular}{|c|c|c|c|c|c|c|}
\hline Fual Prices & 2000 & 2010 & 2020 & 2030 & 2040 & 2050 \\
\hline Gesoline & 1.46 & 1.36 & 1.39 & 1.61 & 1.85 & 210 \\
\hline Diesel & 1.04 & 1.22 & 1.20 & 1.54 & 1.78 & 202 \\
\hline Ntural Ges & 0.98 & 0.80 & 0.8 & 1.06 & 1.18 & 1.29 \\
\hline Ethand & 208 & 1.71 & 1.61 & 1.53 & 1.73 & 200 \\
\hline Hydrogen & 5.00 & 4.00 & 3.50 & 3.17 & 284 & 250 \\
\hline F-TLiesd & 1.86 & 1.44 & 1.48 & 1.70 & 1.89 & 206 \\
\hline Mthand & 1.66 & 1.69 & 1.78 & 1.80 & 1.80 & 1.96 \\
\hline 日ectricity & 1.98 & 220 & 216 & 1.67 & 1.75 & 200 \\
\hline
\end{tabular}

Cthar Key Fud Input Assumptions for LDV.

Share, byviume, in BendedFuds and \% Hohogen from Renenebles

\begin{tabular}{|c|c|c|c|c|c|c|c|c|}
\hline & 2000 & 2010 & 2020 & 2030 & 2040 & 2050 & 1st Year & 1st Y Sh \\
\hline $\begin{array}{l}\text { Bo-Ethand } \\
\text { Elend }\end{array}$ & $0.0 \%$ & $0.0 \%$ & $0.0 \%$ & $0.0 \%$ & $0.0 \%$ & $0.0 \%$ & 0 & $0.0 \%$ \\
\hline F-TLiesd & $0.0 \%$ & $0.0 \%$ & $0.0 \%$ & $0.0 \%$ & $0.0 \%$ & $0.0 \%$ & 0 & $0.0 \%$ \\
\hline $\begin{array}{l}\text { Hyctogen } \\
\text { (reneweble) }\end{array}$ & $0.0 \%$ & $0.0 \%$ & $0.0 \%$ & $0.0 \%$ & $0.0 \%$ & $0.0 \%$ & 0 & $0.0 \%$ \\
\hline
\end{tabular}

Uility Scerario $\Rightarrow$

1

Select fram one of the following:

1- Reference Case (AEOOO2 to 2020)

2- Peneseble Scenario

3-Ntural Ges Scenaio

4-Nuclear Scenario

Figure 2.1 (Cont.) 
WVMVI GrouthRte

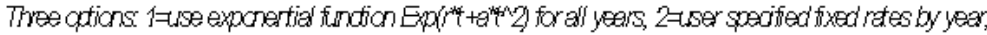

Selected DV

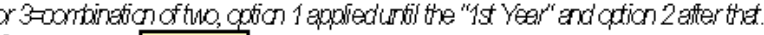

WiT growth

method

\section{3}

WT GrowthFundion $\left.\sim \mathrm{e}^{\mathrm{N}}\left(\mathrm{it}+\mathrm{a}^{\prime}\right)_{2}\right)$

$r=$ rate of granth

$\mathrm{t}=$ time $\boldsymbol{a}$ stat

a= dscart rate

years to zero growth

$-0.000045$

WIT Basticity to Cost of Diving (œrtsimile)

iseory when WMT GouthMthook1

\section{WiT GrouthFactors for Cas}

InoutMT orouth fadtos forcars when the seleded WT Gouth Mathodis 20 r 3

MUST spojify the first year and fist year WIT fator.

\begin{tabular}{|c|c|c|c|c|c|c|c|c|}
\hline $\begin{array}{l}\text { Car WhI Factor } \\
\text { for the Decade } \\
\text { Year }\end{array}$ & 2000 & $\begin{array}{c}2001- \\
2010 \\
\end{array}$ & $\begin{array}{l}2011-1 \\
2020\end{array}$ & $\begin{array}{c}2001 \text { - } \\
2030\end{array}$ & $\begin{array}{l}2031 \text { - } \\
2040\end{array}$ & $2041-2050$ & Ist Year & $\begin{array}{l}\text { 1stYr } \\
\text { WIT } \\
\text { Factar }\end{array}$ \\
\hline 1 & & & 1.0139 & 1.0123 & 1.0104 & 1.0000 & 2002 & 1.0069 \\
\hline 2 & & 1.0059 & 1.0146 & 1.0124 & 1.0102 & 1.0000 & \multirow{9}{*}{ CARS } & \\
\hline 3 & & 1.0079 & 1.0145 & 1.0122 & 1.0100 & 1.0090 & & \\
\hline 4 & & 1.0081 & 1.0129 & 1.0120 & 1.0097 & 1.0090 & & \\
\hline 5 & & 1.0082 & 1.0132 & 1.0118 & 1.0005 & 1.0000 & & \\
\hline 6 & & 1.0054 & 1.0144 & 1.0115 & 1.0004 & 1.0068 & & \\
\hline 7 & & 1.0078 & 1.0142 & 1.0113 & 1.0093 & 1.0065 & & \\
\hline 8 & & 1.0115 & 1.0138 & 1.0111 & 1.0092 & 1.0063 & & \\
\hline 9 & & 1.0122 & 1.0147 & 1.0108 & 1.0091 & 1.0000 & & \\
\hline 0 & & 1.0125 & 1.0130 & 1.0106 & 1.0090 & 1.0078 & & \\
\hline
\end{tabular}

WIT GrouthFators for Lidt Trudks

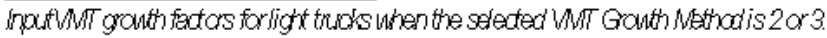

MLST specify the firs year and fis year WMi fator.

\begin{tabular}{|c|c|c|c|c|c|c|c|c|}
\hline $\begin{array}{l}\text { Dir Wirl Factor } \\
\text { for the Decade } \\
\text { Year }\end{array}$ & 2000 & $\begin{array}{l}2001 \text { - } \\
2010\end{array}$ & $\begin{array}{l}2011 \text { - } \\
2020\end{array}$ & $\begin{array}{c}2001 \text { - } \\
2030\end{array}$ & $\begin{array}{l}2031 \text { - } \\
2040\end{array}$ & $2041-2050$ & 1st Year & $\begin{array}{l}\text { TstYr } \\
\text { WIT } \\
\text { Factar }\end{array}$ \\
\hline 1 & & & 1.0348 & 1.0188 & 1.0127 & 1.0104 & 2002 & 1.0514 \\
\hline 2 & & 1.0514 & 1.0325 & 1.0181 & 1.0124 & 1.0101 & \multirow{9}{*}{\multicolumn{2}{|c|}{ பGா TRUCKS }} \\
\hline 3 & & 1.0535 & 1.0003 & 1.0175 & 1.0121 & 1.0097 & & \\
\hline 4 & & 1.0465 & 1.0270 & 1.0169 & 1.0118 & 1.0094 & & \\
\hline 5 & & 1.0450 & 1.0256 & 1.0162 & 1.0115 & 1.0090 & & \\
\hline 6 & & 1.0415 & 1.0249 & 1.0156 & 1.0114 & 1.0068 & & \\
\hline 7 & & 1.0404 & 1.0235 & 1.0149 & 1.0112 & 1.0066 & & \\
\hline 8 & & 1.0406 & 1.0022 & 1.0143 & 1.0111 & 1.0063 & & \\
\hline 9 & & 1.0398 & 1.0220 & 1.0136 & 1.0100 & 1.0081 & & \\
\hline 0 & & 1.0365 & 1.0193 & 1.0130 & 1.0108 & 1.0079 & & \\
\hline
\end{tabular}

Figure 2.1 (Cont.) 


\section{Lidt VetideCostRatio}

CarBase Pice 20,000

\begin{tabular}{l|cccccc} 
Techndogy & $\mathbf{2 0 0 0}$ & $\mathbf{2 0 1 0}$ & $\mathbf{2 0 2 0}$ & $\mathbf{2 0 3 0}$ & $\mathbf{2 0 4 0}$ & $\mathbf{2 0 5 0}$ \\
\hline EV & 1.08 & 1.10 & 1.10 & 1.10 & 1.10 & 1.10 \\
E-85 & 0.00 & 0.00 & 0.00 & 0.00 & 0.00 & 0.00 \\
Diesd & 000 & 0.00 & 0.00 & 0.00 & 0.00 & 0.00 \\
ONG & 000 & 0.00 & 0.00 & 0.00 & 0.00 & 0.00 \\
Hytrid & 0.00 & 1.10 & 1.10 & 1.10 & 1.10 & 1.10 \\
Fud Cell & 0.00 & 1.15 & 1.15 & 1.15 & 1.15 & 1.15 \\
\hline
\end{tabular}

LtTrkBase 20,000

\begin{tabular}{l|cccccc} 
Tectrology & $\mathbf{2 0 0 0}$ & $\mathbf{2 0 1 0}$ & $\mathbf{2 0 2 0}$ & $\mathbf{2 0 0 3 0}$ & $\mathbf{2 0 4 0}$ & $\mathbf{2 0 5 0}$ \\
\hline EV & 1.08 & 1.10 & 1.10 & 1.10 & 1.10 & 1.10 \\
E-85 & 000 & 0.00 & 000 & 0.00 & 0.00 & 0.00 \\
Diesed & 0.00 & 0.00 & 000 & 0.00 & 0.00 & 0.00 \\
ONG & 0.00 & 0.00 & 000 & 0.00 & 0.00 & 0.00 \\
Hytrid & 1.00 & 1.10 & 1.10 & 1.10 & 1.10 & 1.10 \\
Fud Cell & 0.00 & 1.15 & 1.15 & 1.15 & 1.15 & 1.15 \\
\hline
\end{tabular}

Figure 2.1 (Cont.) 
Default values for the certification test fuel economy of alternative fuel and advanced technology vehicles are provided in VISION. These values are derived from AEO 2002 reference case estimates. Alternative values may be input to the model. Whichever values are used, on-road, average fleet fuel economy of and total fuel use by alternative fuel and advanced technology vehicles are determined in the same manner as that described for conventional vehicles in Sections 2.1.4-2.1.6. The only difference is that on-road fuel economy is estimated to be $85 \%$ of the certification test fuel economy for HEVs and FCVs and $100 \%$ for EVs versus $80 \%$ for ICE vehicles.

Total fuel use by type of fuel is calculated in VISION. As indicated previously, the hybrid and fuel cell vehicles may use any one of several fuels: gasoline, diesel fuel, natural gas, ethanol, methanol, and hydrogen. Gasoline used by these vehicles and ICEs may include ethanol blends. Diesel fuel used by diesels and HEVs may include diesel fuel produced by the F-T process from natural gas. The E-85 used by E-85 vehicles includes gasoline. The process for assigning total fuel use by fuel type is straightforward. Ultimately, total fuel use is disaggregated into oil (gasoline and non-F-T diesel), CNG, F-T diesel, ethanol, methanol, hydrogen, and electricity.

Total carbon emissions of the alternative fuel and advanced technology vehicles are estimated in VISION. The carbon coefficients for all alternative fuels and blends are full fuel cycle and are derived from the GREET model. The coefficients of various fuels may vary over time, depending on input assumptions regarding the percentage of ethanol blends in gasoline, Fischer-Tropsch diesel used to produce diesel fuel, renewables use to produce hydrogen, and resource fuels used in electricity production. Four future utility mixes are provided. Also, the carbon emissions generated by hybrids and fuel cell vehicles vary, depending on which of the approximately six fuels are assumed to be used. Finally, ethanol is assumed to be $100 \%$ cellulosic.

\subsubsection{Alternative Car-Light Truck Split}

The Base Case assumes a 50-50 split of new LV sales beginning in 2001. Alternative cases can be run that alter that ratio. However, if the user wants to maintain the annual VMT per vehicle estimates used in the Base Case, the default total VMT growth rates (described in Section 2.1.3) need to modified.

(In Figure 2.1, "Yes" is input under the cell titled "Change Lt Truck Share?" to indicate that the default 50-50 split is a change from the EIA share estimates contained in the model. If the EIA shares are to be used, "No" would be input.)

\subsubsection{Alternative Fuel Prices}

VISION includes default fuel price/gallon estimates for all alternative fuels. AEO 2002 is the source of the estimates to 2020. Post-2020, it is assumed that the real price of all fuels will rise, except for hydrogen and electricity. (Ethanol's price falls until 2030, but then it rises to near2000 levels by 2050.) The use can modify these prices (as well as that of gasoline). Whichever prices are assumed, VISION uses the prices combined with total fuel use estimates by type of fuel to calculate annual total fuel expenditures. 


\subsubsection{Alternative VMT Estimates and VMT Elasticity Effect}

VISION allows a user to select an alternative method of projecting future VMT growth, as compared with that used in the Base Case. Two methods are available: (1) an exponential function and (2) alternative multiplicative annual growth factors. As a third method, it is possible to select the exponential function (method 1 ) up to a selected year and then switch to annual VMT growth factors (method 2).

The first method computes total VMT by using an exponential function and applies a userspecified elasticity to fuel cost per mile relative to the Base Case. The exponential function is calibrated such that it produces the desired annual VMT/vehicle when divided by vehicle stock. In method 2, the user may replace the default growth rates of the Base Case (which are described in Section 2.1.3).

The main advantage of using the exponential function method to estimate VMT growth is that it allows the user to incorporate the effect on a scenario's total VMT and total fuel use of VMT elasticity to the cost of driving (i.e., driving more when fuel costs/mile decrease because of improved vehicle fuel economy and vice versa). Fuel cost per mile is automatically derived from fuel prices, given the fuel economy assumptions of the scenario. The historical value of such VMT elasticity is approximately -0.2 (i.e., a $2 \%$ increase in VMT results from a $10 \%$ reduction in fuel cost $/$ mile). VISION uses -0.2 as a default value, but other values may be used.

Using these alternative estimates of VMT for a scenario requires that a new Base Case be developed that incorporates the alternative VMT growth rates. This new Base Case is, in effect, a scenario. The user compares the higher-MPG scenario (which can include higher-MPG alternative fuel vehicles, as well as gasoline-fueled vehicles) with this new Base Case scenario.

Finally, a user may also change the rate of growth parameter of the exponential function within method 1, as well as the discount rate and year-to-zero growth parameters. VISION includes default values for these variables. The new Base Case must have the same values for these parameters as any alternative case with which it is compared.

\subsubsection{Incremental Vehicle Costs}

VISION allows the user to input the expected ratio of the cost of new alternative fuel and advanced technology vehicles relative to the cost of new conventional vehicles. The car and light truck base price are both assumed to be $\$ 20,000 / v e h i c l e$, but it can be modified. The model then calculates to the total incremental new vehicle costs of a scenario.

\subsection{Light Vehicles in VISION 2.0}

The main difference in the light vehicle data and assumptions underlying VISION 1.1.2 and VISION 2.0 is that VISION 2.0 incorporates updates of data and estimates provided by various references used in VISION 1.1.2. Historical data in general have been updated to 2001. Such data are provided in EIA's Annual Energy Review, in FHWA and Census reports, and in the Transportation Energy Data Book (TEDB) $(3,5,7,9)$. 
VISION 2.0 also uses the latest EIA AEO 2003 estimates of total vehicle sales, energy prices, and GDP (2). Some estimates remain to be updated (e.g., EIA AEO's utility fuel mix estimates).

In VISION 2.0, EIA annual VMT per vehicle estimates are not adhered to as closely as they are in VISION 1.1.2. EIA AEO 2003 projects a substantial difference in the annual VMT of cars and light trucks by 2025: a difference of nearly 1,000 mi/yr. VISION 2.0 instead assumes that the annual VMT per car and light truck will be the same from about 2012 onward. EIA projects that in 2012, cars will overtake light trucks in annual miles per vehicle. In VISION 2.0, cars and light trucks are predicted to be traveling $15,000 \mathrm{mi} / \mathrm{yr}$ by 2050 , as in VISION 1.1.2. 
$\Delta$ 


\section{Section 3 \\ Methodology and Input Data: Heavy Vehicles}

As stated in Section 2, VISION contains a Base Case projection of U.S. highway transportation energy use to 2050. As much as possible, it relies on EIA AEO projections, but there are some key differences. This section of the report explains the derivation of the Base Case projection for heavy vehicles and how it can be modified in the model to evaluate alternative assumptions about the market penetration of advanced technologies, alternative fuels, and higherfuel-economy vehicles. Key differences between the methodology used in VISION 1.1.2 and VISION 2.0 are briefly described.

\subsection{Heavy Vehicle Base Case: VISION 1.1.2}

Heavy vehicles in VISION include trucks in Class 3-8. Trucks in Class 3-6 are referred to as medium or medium-duty trucks. Trucks in Class $7-8$ are referred to as heavy or heavy-duty trucks. As stated in Section 2, Class 2B trucks are included with light vehicles in VISION. Heavy vehicle energy and oil use and carbon emissions are determined by the total number of trucks in operation, the total number of miles they travel, their energy efficiency, and the fuels they use. The derivation of these estimates is explained below.

\subsubsection{Vehicle Sales, Stock, and Total VMT to 2020}

Vehicle sales, stock, and VMT are disaggregated into medium trucks and heavy trucks. Historical data were obtained from the Transportation Energy Data Book, Ward's Motor Vehicle Facts \& Figures, and FHWA's Highway Statistics $(3,4,7)$. Because separate stock and travel (VMT) estimates for heavy trucks and medium trucks were not available for 1990-2000, estimation factors were developed on the basis of an analysis of the 1987 and 1992 Truck Inventory and Use Surveys, 1997 Vehicle Inventory and Use Survey, and AEO 2002 projections (10-12). The single unit truck stock was estimated as $27 \%$ heavy truck and $73 \%$ medium truck, while single unit truck travel was distributed as $30 \%$ heavy truck and $70 \%$ medium truck. Sales, stock, and VMT projections to 2020 were derived from AEO 2002 (1).

\subsubsection{Vehicle Sales, Stock, and Total VMT Post-2020}

The post-2020 estimates of heavy vehicle sales, stock, and VMT were taken from the Base Case of a joint DOE/Natural Resources Canada study of North American transportation energy futures (hereafter referred to as the Phase 22050 Study) (13). In the Phase 22050 Base Case, trends projected by EIA to 2020 for heavy vehicle use were generally assumed to continue post2020. Heavy vehicle sales, stock, and VMT were tied to GDP growth.

Table 3.1 presents the medium and heavy truck sales, stock, and VMT estimates developed for the Phase 22050 Study Base Case and used in the VISION Base Case. The projected Gross 


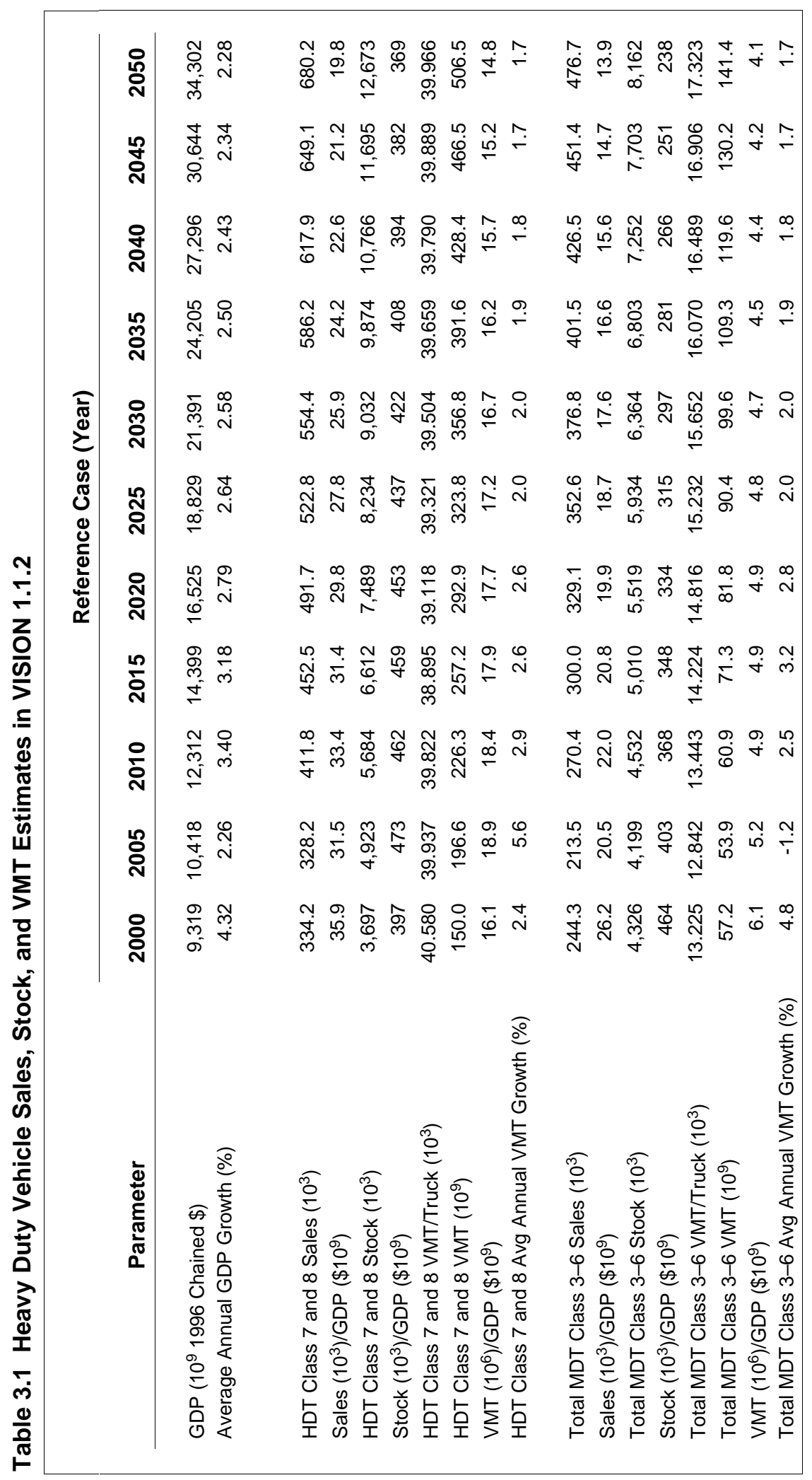


Domestic Product (GDP) estimates used in VISION differ somewhat from those of the Phase 2 2050 study, but VISION uses the study's annual estimates of heavy vehicle sales, stock, and VMT estimates directly.

VISION contains a heavy vehicle stock model in which historical and projected sales are combined with historical vehicle survival rates to make an initial calculation of heavy vehicle stock by year. (This calculation is made separately for medium and heavy trucks.) Subsequently, the vehicle stock by age of vehicle in any year is combined with historical rates of annual travel by age of vehicle to develop initial total VMT estimates for that year. These initial estimates were then corrected to match the Phase 22050 Study stock and VMT estimates.

Of the three variables (sales, stock, and VMT), the final VMT estimates directly impact energy use and thus are the most important in VISION. In the Phase 22050 Study, regression models that provide an estimate of truck travel per billion dollars of GDP were developed. These models were forced to have no constant parameters. The analysis estimated 17.7 million heavy truck VMT per billion dollars GDP (in 1996 chained dollars) and 4.9 million medium truck VMT per billion dollars GDP in 2020. Figure 3.1 shows historical and AEO 2002 projections along with the regression model results. These models were used for the 2021-2050 total VMT projections. The VMT per billion dollars GDP rate was gradually lowered in later years. The resulting VMT estimates were used in the Phase 22050 Study and subsequently in VISION.

\subsubsection{Fuels}

Both gasoline and diesel fuel are used by heavy vehicles. In VISION, sales and stock of conventional heavy vehicles are not disaggregated into gasoline and diesel vehicles. However, VMT and energy use by conventional heavy vehicles are disaggregated into travel and energy use by gasoline and diesel heavy vehicles (see Section 3.1.5). EIA projects limited market penetration of alternative fuel (natural gas, LPG) heavy vehicles. However, the Base Case assumes no such penetration.

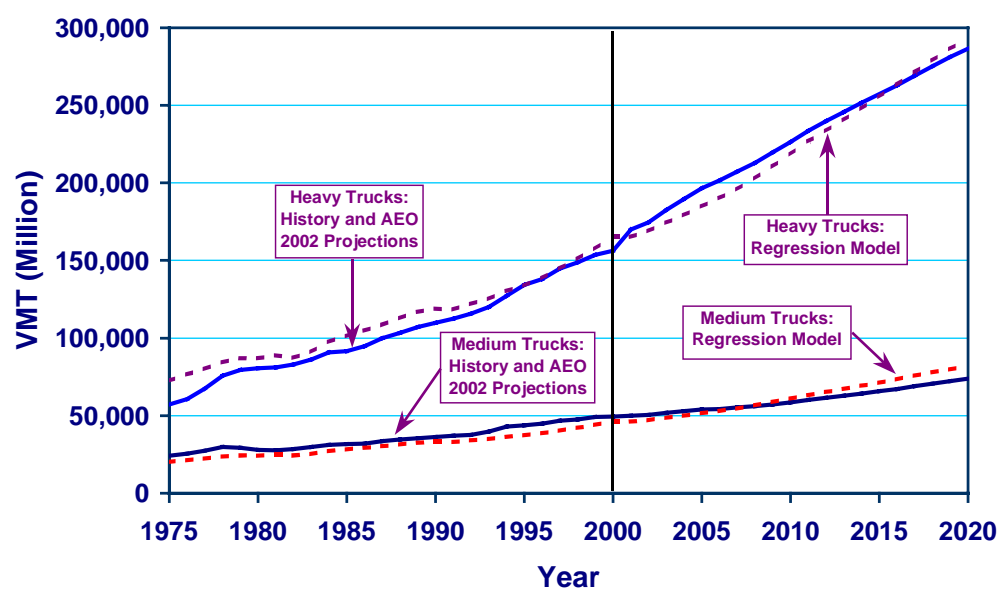

Figure 3.1 Heavy and Medium Truck VMT Projections 


\subsubsection{Fuel Economy}

The fuel economy of new medium trucks is held constant from 2000 to 2050 at 8.16 MPG. This fuel economy represents the combined fuel economy of medium gasoline and diesel trucks. Similarly, the fuel economy of new heavy trucks is held constant from 2000 to 2050 at 5.54 MPG and represents the combined fuel economy of heavy gasoline and diesel trucks (over $99 \%$ of heavy truck VMT are by diesel trucks). These values are similar to, but not the same as, EIA's AEO 2002 estimates. As with light vehicles, VISION uses a fixed MPG Base Case because the objective of many analyses is to evaluate the effects of new technology penetration relative to existing technology.

VISION calculates average fleet fuel economy for each year. It uses historical values for VMT use by vehicle age, vehicle stock by age by calendar year, and on-road vehicle fuel economy by calendar year to generate these estimates. Compared with light-duty vehicles, medium and heavy trucks do not have any fuel economy test procedures. It is customary to report on-road fuel economy for new trucks. Consequently, there are no on-road degradation factors to be applied in the model, and on-road fuel economy of new heavy vehicles is used as input.

\subsubsection{Total Fuel Use by Fuel Type}

Total fuel use by gasoline and diesel medium trucks for any year is estimated by (1) disaggregating total VMT into VMT in diesel trucks and gasoline trucks and (2) multiplying these separate VMT totals by the energy efficiency (Btu/mi) of the gasoline and diesel trucks. Because the energy content of a gallon of diesel fuel and gasoline differs, the energy efficiency of the gasoline and diesel medium trucks varies, even when a combined fuel economy is input. The diesel share of medium truck VMT through 2020 is derived from EIA's AEO 2002 estimates. Diesel VMT grows from approximately $67 \%$ to $84 \%$ of total medium truck VMT in that period. (EIA's estimates of VMT by alternative fuel trucks are ignored.) The post-2020 estimates assume a continuing dieselization, reaching $95 \%$ by 2050 .

Total fuel use by gasoline and diesel heavy trucks for any year is estimated in the same manner as that for medium trucks. Heavy vehicles are already virtually all diesel (99\%), but even that percentage increases by $2050(99.7 \%)$.

\subsubsection{Total Carbon-Equivalent Emissions}

Total carbon emissions are estimated by using a carbon coefficient per unit of gasoline or diesel fuel consumed in the Base Case. As discussed in Section 2.1.7, the carbon coefficient for each fuel represents full fuel cycle emissions associated with gasoline and diesel fuel use and accounts for the global warming potential of three pollutants. The coefficients were estimated by using the GREET model (8) and are invariant across years. The baseline gasoline contains no ethanol blends, and the baseline diesel fuel is not produced from biodiesel or Fischer-Tropsch diesel, which have different coefficients than those for conventional diesel fuel. 


\subsubsection{Total Fuel Expenditures}

VISION includes fuel price per gallon estimates for gasoline and diesel fuel (including taxes). AEO 2002 is the source of the estimates to 2020. Post-2020, it is assumed that the real price of gasoline will rise to $\$ 2.10 /$ gal by 2050 and that diesel will be approximately $96 \%$ of that on a gasoline-equivalent-gallon basis. Given these price assumptions and total fuel use estimates, VISION calculates annual total fuel expenditures for heavy vehicles.

\subsection{Heavy Vehicle Alternative Scenarios: VISION 1.1.2}

Figure 3.2 presents the variables in VISION that can easily be modified to create alternative scenarios of heavy vehicle energy use. The figure is a copy of the heavy vehicle portion of the VISION Model Input sheet. Market penetration of natural-gas and hydrogen-fueled trucks can be simulated, and the following parameters can be varied:

- Fuel economy of these vehicle types and conventional trucks,

- Diesel share of conventional truck VMT,

- Share of F-T diesel and biodiesel used in diesel fuel production, and

- Percentage of hydrogen produced from renewable resources.

The following discussion describes how the VISION model user can change these variables to create alternative scenarios of fuel use.

Besides changing the variables shown in Figure 3.1, other inputs may be hard-wired into VISION runs. For example, as with the light vehicles, VISION uses linear interpolation for market penetration estimates. Alternative assumptions may be hard-wired into the model for specific runs. We do not discuss such assumptions in this section.

Finally, we should point out that, unlike with the light vehicles, total VMT by heavy vehicles cannot be modified. The relative share of medium trucks as a component of total heavy vehicles cannot be modified, either. Inputs that would change total VMT or medium truck share would have to be hard-wired into the model.

\subsubsection{Higher-Fuel-Economy Conventional Heavy Vehicles}

Given a start date and a ratio of higher-fuel-economy conventional heavy vehicles to Base Case conventional heavy vehicles, the model generates an alternative average fleet fuel economy and thus a different total fuel use, as compared with those estimated in the Base Case.

\subsubsection{Market Penetration of Alternative Fuel and Advanced Technology Vehicles}

Given a start date and percentage of new alternative fuel and advanced technology vehicles sold in 2010,2020, 2030, 2040, and 2050, the model generates estimates of the percentage of 
total heavy vehicle sales of these vehicles in all years by using linear interpolation for the intervening years. These sales are converted into alternative fuel and advanced technology vehicles stock and VMT by using the heavy vehicle stock model and correction factors discussed in Section 3.1.2. These estimates are then subtracted from the total vehicle sales, stock, and VMT estimates of the Base Case to estimate the modified conventional vehicle sales, stock, and VMT for the scenario.

Default values for the new (and thus on-road) fuel economy of alternative fuel and advanced technology vehicles are provided in VISION. Alternative fuel economy values may be input to the model. Whichever values are used, on-road, average fleet fuel economy, and total fuel use by type of alternative fuel and advanced technology heavy vehicles are determined in the same manner as that described for conventional vehicles in Sections 3.1.4-3.1.5.

Ultimately, total fuel use is disaggregated into oil (gasoline and non-F-T diesel), F-T diesel, biodiesel, natural gas, and hydrogen. The model does not report the use of ethanol blended into gasoline used in heavy vehicles. Only if a scenario covering both light and heavy vehicles assumed some use of ethanol blends in gasoline used by light vehicles would any use of ethanol blends by heavy vehicles occur. The volume could be estimated exogenously.

Total carbon emissions of the alternative fuel and advanced technology heavy vehicles are also estimated. Similar to the values for light vehicles, the carbon coefficients for all alternative fuels are full fuel cycle and are derived from the GREET model. The coefficient of hydrogen used in heavy vehicles will vary over time if some renewables are assumed to produce hydrogen. The carbon coefficients for conventional diesel fuel, biodiesel, and F-T diesel differ from one another. If ethanol blends are assumed to be used in gasoline for light vehicles, then the carbon coefficient of the gasoline used in heavy vehicles accounts for that use.

\subsubsection{Alternative Fuel Prices}

VISION includes default fuel price/gallon estimates for gasoline, diesel fuel, and alternative fuels. AEO 2002 is the source of the estimates to 2020. Post-2020, it is assumed that the real price of all the fuels, except for hydrogen, will rise. The use can modify these prices. Whichever prices are assumed, VISION uses the prices combined with total fuel use estimates by type of fuel to calculate annual total fuel expenditures.

\subsection{Heavy Vehicles in VISION 2.0}

The main difference in the heavy vehicle data and assumptions underlying VISION 1.1.2 and VISION 2.0 is that VISION 2.0 incorporates updates of data and estimates provided by various references used in VISION 1.1.2. Historical data in general have been updated to 2001 . Such data are provided in EIA's Annual Energy Review, Ward's Motor Vehicle Facts \& Figures, FHWA and U.S. Census Bureau reports, and in the Transportation Energy Data Book $(3,4,5,7,9)$.

The regression equations used to estimate 2021-2050 total sales, stock, and VMT in VISION 1.1.2 are used in VISION 2.0. The equations are applied to the last projection year of AEO 2003 and all subsequent years. Year-to-year growth factors are computed and applied to the data for the last projection year of AEO 2003. As a result of this update, both the total sales and 
stock estimates were increased over those of VISION 1.1.2. Total VMT for Class 3-8 is slightly higher than VMT in VISION 1.1.2, although the total VMT for Class 3-6 is lower.

VISION 2.0 uses the same default values for advanced and alternative fuel heavy vehicle fuel economy to 2025 as are in VISION 1.1.2. 
HEAVY VEHICLES

Vehicle Efficien cy

Reference Combined Gasoline and Diesel Fuel Economy

\begin{tabular}{|l|cccccc|}
\hline & 2000 & 2010 & 2020 & 2030 & 2040 & 2050 \\
\hline Medium (3-6) & $\mathbf{8 . 1 6}$ & $\mathbf{8 . 1 6}$ & $\mathbf{8 . 1 6}$ & $\mathbf{8 . 1 6}$ & $\mathbf{8 . 1 6}$ & $\mathbf{8 . 1 6}$ \\
Heavy (7\&8) & 5.54 & 5.54 & 5.54 & 5.54 & 5.54 & 5.54 \\
\hline
\end{tabular}

\begin{tabular}{|c|c|c|c|c|c|c|c|}
\hline lew Trugk MPGRa & 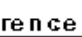 & & & & & 1st Year & $M P G$ in \\
\hline & 2010 & 2020 & 2030 & 2040 & 2050 & of Change & $1 \mathrm{st}$ Year \\
\hline Medium: Conv Gas \& Dsl & 1.00 & 1.00 & 1.00 & 1.00 & 1.00 & $\overline{0}$ & 0.00 \\
\hline Medium: Natural Gas & 1.00 & 1.01 & 1.02 & 1.02 & 1.02 & $\mathbf{0}$ & 0.00 \\
\hline Mediu m: Hydrogen & 1.05 & 1.10 & 1.15 & 1.20 & 1.25 & 0 & 0.00 \\
\hline Heavy: ConvGas \& DsI & 1.00 & 1.00 & 1.00 & 1.00 & 1.00 & 0 & 0.00 \\
\hline Heavy: Natural Gas & 0.92 & 0.98 & 1.00 & 1.00 & 1.00 & $\mathbf{0}$ & 0.00 \\
\hline Heavy: Hydrogen & 1.05 & 1.10 & 1.15 & 1.20 & 1.25 & 0 & 0.00 \\
\hline
\end{tabular}

Natural Gas \& Hydrogen Powered Truck Market Shares (Rest assumedas Conventional)

\begin{tabular}{|c|c|c|c|c|c|c|c|}
\hline & 2010 & 2020 & 2030 & 2040 & 2050 & 1stYear & 1stYrShr \\
\hline Medium: Natural Gas & $0.0 \%$ & $0.0 \%$ & $0.0 \%$ & $0.0 \%$ & $0.0 \%$ & 2000 & $0.0 \%$ \\
\hline Medium: Hydrogen & $0.0 \%$ & $0.0 \%$ & $0.0 \%$ & $0.0 \%$ & $0.0 \%$ & 2000 & $0.0 \%$ \\
\hline Heavy: Natural Gas & $0.0 \%$ & $0.0 \%$ & $0.0 \%$ & $0.0 \%$ & $0.0 \%$ & 2000 & $0.0 \%$ \\
\hline Heavy: Hydrogen & $0.0 \%$ & $0.0 \%$ & $0.0 \%$ & $0.0 \%$ & $0.0 \%$ & 2000 & $0.0 \%$ \\
\hline
\end{tabular}

\begin{tabular}{|c|c|c|c|c|c|c|c|c|}
\hline Diesel Share & c & tional & In & $t$ & 8 & e) & 1st Year & Share in \\
\hline & 2000 & 2010 & 2020 & 2030 & 2040 & 2050 & of Change & 1st Year \\
\hline $\begin{array}{l}\text { Medium: Conv } \\
\text { Heavy: Conv }\end{array}$ & $\begin{array}{l}67.2 \% \\
99.0 \%\end{array}$ & $\begin{array}{l}78.1 \% \\
99.3 \%\end{array}$ & $\begin{array}{l}84.3 \% \\
99.3 \%\end{array}$ & $\begin{array}{l}92.9 \% \\
99.4 \%\end{array}$ & $\begin{array}{l}95.0 \% \\
99.5 \%\end{array}$ & $\begin{array}{l}95.0 \% \\
99.7 \%\end{array}$ & $\begin{array}{l}0 \\
0\end{array}$ & $\begin{array}{l}0.00 \\
0.00\end{array}$ \\
\hline
\end{tabular}

F-T and Bio-Diesel Share of Diesel Fuel Use by Heavy Vehicles

\begin{tabular}{|c|c|c|c|c|c|c|c|c|}
\hline & 2000 & 2010 & 2020 & 2030 & 2040 & 2050 & 1st Year & 1st YrShr \\
\hline \begin{tabular}{|l|} 
Bio-Diesel \\
F-T Diesel
\end{tabular} & $\begin{array}{l}0.0 \% \\
0.0 \%\end{array}$ & $\begin{array}{l}0.0 \% \\
0.0 \%\end{array}$ & $\begin{array}{l}0.0 \% \\
0.0 \%\end{array}$ & $\begin{array}{l}0.0 \% \\
0.0 \%\end{array}$ & $\begin{array}{l}0.0 \% \\
0.0 \%\end{array}$ & $\begin{array}{l}0.0 \% \\
0.0 \%\end{array}$ & $\begin{array}{l}0 \\
0\end{array}$ & $\begin{array}{l}0.0 \% \\
0.0 \%\end{array}$ \\
\hline
\end{tabular}

Share of Hydrogen from Renewable Sources for Heavy Duty Use

\begin{tabular}{|c|c|c|c|c|c|c|c|c|}
\hline & 2000 & 2010 & 2020 & 2030 & 2040 & 2050 & 1st Year & 1st YrShr \\
\hline $\begin{array}{l}\text { Hydrogen } \\
\text { (Renewable) }\end{array}$ & $0.0 \%$ & $0.0 \%$ & $0.0 \%$ & $0.0 \%$ & $0.0 \%$ & $0.0 \%$ & $\mathbf{0}$ & $0.0 \%$ \\
\hline
\end{tabular}

Figure 3.2 Heavy Vehicle VISION Model Inputs 


\section{Section 4 \\ Potential Enhancements}

VISION 2.0 will be the model to which changes are made in the future. Enhancements that would be useful most immediately include the following:

1. Update the current carbon coefficients for fuels to the most recent GREET estimates. VISION currently uses coefficients from GREET 1.6 as of September 2001. The update might include updating coefficients to account for changes over time. GREET is currently being modified to do just that.

2. Add more resource fuels for $\mathrm{H}_{2}$. Currently, only the carbon coefficients of natural gas to $\mathrm{H}_{2}$ and renewables to $\mathrm{H}_{2}$ are included.

3. With interest in light-duty diesel vehicles growing, disaggregate existing diesel LDV sale, stock, VMT, and fuel use from gasoline vehicles.

Less-immediate enhancements might include the following:

1. Disaggregate Class 3-6 heavy truck sales, stock, and VMT into their gasoline and diesel fuel components. Class 7-8 does not need to be disaggregated since $99 \%$ of the VMT of these trucks is by diesel trucks.

2. Automate the process for inputting the relative vehicle fuel economy ratios of non-gasoline fuels to the fuel economy of the baseline gasoline vehicle.

3. Allow the input of data at 5-yr, rather than just 10-yr, intervals.

4. Add the use of biodiesel as LDV diesel additive. It is now only included as a $H D V$ diesel additive.

5. Allow the hybrid electric vehicles to use multiple fuels (gasoline, E85, and diesel).

6. Show the ethanol results by the amount used in gasoline blends (E-10), E-85, and E-100 separately.

7. Add the capability to more easily compare scenarios to EIA's Reference Case. As discussed in Sections 2 and 3, the VISION Base Case incorporates many EIA projections, but not all. In particular, assumptions about new vehicle fuel economy differ and, in VISION 2.0, LDV VMT differs post2012. Ideally, a process that facilitates use of EIA's assumptions about fuel economy and VMT to 2025 would be helpful. 
$\Delta$

8. Add the capability of automatically assuming S-curves for 20-, 30-, 40-yr vehicle market penetration.

Other enhancements can be made as the need arises. 


\section{Section 5 References}

1. U.S. Department of Energy, 2001, Annual Energy Outlook 2002 with Projections to 2020, DOE/EIA-0383 (2002), Energy Information Administration, Washington, D.C., Dec.

2. U.S. Department of Energy, 2003, Annual Energy Outlook 2003 with Projections to 2025, DOE/EIA-0383 (2003), Energy Information Administration, Washington, D.C., Jan.

3. Davis, S.C, et al., 2002, Transportation Energy Data Book: Edition 22, ORNL-6967, Oak Ridge National Laboratory, Oak Ridge, Tenn., Sept.

4. Wards, 2002, WARD'S Motor Vehicle Facts \& Figures 2002, Ward's Communications, Southfield, MI.

5. U.S. Census Bureau, 2000, Annual Projections of the Total Resident Population as of July 1: Middle, Lowest, Highest, and Zero International Migration Series, 1999 to 2100, U.S. Department of Commerce, U.S. Census Bureau, Washington, D.C., Feb.

6. Mintz, M., et al., 1998, IMPACTT5A Model: Enhancements and Modifications since December 1994, ANL/ESD/TM-154, Argonne National Laboratory, Argonne, Ill., Sept.

7a. Federal Highway Administration, 1997, Highway Statistics Summary to 1995, FHWA-PL97-009, U.S. Department of Transportation, Washington, D.C.

7b. Federal Highway Administration, 1998, Highway Statistics 1997, FHWA-PL-98-020, U.S. Department of Transportation, Washington, D.C.

7c. Federal Highway Administration, 1999, Highway Statistics 1998, FHWA-PL-99-017, U.S. Department of Transportation, Washington, D.C.

7d. Federal Highway Administration, 2000, Highway Statistics 1999, FHWA-PL-00-020, U.S. Department of Transportation, Washington, D.C.

7e. Federal Highway Administration, 2001, Highway Statistics 2000, FHWA-PL-01-011, U.S. Department of Transportation, Washington, D.C.

7f. Federal Highway Administration, 2002, Highway Statistics 2001, FHWA-PL-02-008, U.S. Department of Transportation, Washington, D.C.

8. Wang, M.Q., 2001, Development and Use of GREET 1.6 Fuel-Cycle Model for Transportation Fuels and Vehicle Technologies, ANL/ESD/TM-163, Argonne National Laboratory, Argonne, Ill., June. 
9. U.S. Department of Energy, 2002, Annual Energy Review 2001, DOE/EIA-0384(2001), Energy Information Administration, Washington, D.C.

10. U.S. Census Bureau, 1990, 1987 Truck Inventory and Use Survey: Public Use Tape, U.S. Department of Commerce, Washington, D.C.

11. U.S. Census Bureau, 1995, 1992 Truck Inventory and Use Survey: Public Use Tape, U.S. Department of Commerce, Washington, D.C.

12. U.S. Census Bureau, 2000, 1997 Vehicle Inventory and Use Survey: Microdata File, U.S. Department of Commerce, Washington, D.C.

13. Patterson, P., et al., 2003, Joint DOE/NRCan Study of North American Transportation Energy Futures: Discussion of the Study and Presentation of Phase 2 results, presentation to U.S. DOE, Washington, D.C., April.

14. Greene, D., et al., 1990, Alternative Motor Fuel Use Model-Model Theory and Design and User's Guide, ORNL/TM-11448, Oak Ridge National Laboratory, Oak Ridge, Tenn., March.

15. Mintz, M., et al., 1993, Differences between EPA-Test and In-Use Fuel economy: Are the Correction Factors Correct?, Transportation Research Board, Transportation Research Record 1416. 


\section{Appendix A \\ How to Use VISION}

VISION 1.1.2 consists of 2 Excel workbooks: "VISION 1.1.2 Fixed MPG Base Case with AEO 2002 Data" and "File to be copied for all runs using VISION 1.1.2 Fixed MPG Base Case." For each run of the model, only the "File to be copied..." should be opened and saved under a different name. Ideally, the name would reflect the underlying assumptions of the specific run. When opening the file, the user should answer "No" to the question about updating all linked information.

"File to be copied...," and thus its copy, are linked to "VISION 1..1.2 Fixed MPG Base Case... ." In particular, the links are to the "results" of the Fixed MPG Base Case. This means that when inputs are made to the copied file on its "Model Input" sheet, the results of the run are compared directly to the Fixed MPG Base Case on the copied file's "Model Results" sheet (as well as several other sheets).

The "Model Input" sheet allows the user to input various assumptions about the future of vehicle technology and vehicle use (e.g., market penetration of various light and heavy vehicle advanced technologies, vehicle energy efficiency, alternative fuel use, VMT, auto vs. light truck share of total light-duty-vehicle sales). Figure 2.1 shows the light vehicle component of this sheet. In particular, all items highlighted in yellow on the sheet can be modified [WILL THE

REPORT BE PUBLISHED IN COLOR?]. The assumptions are generally input in 10-yr increments: 2000, 2010, 2020, 2030, 2040, and 2050. However, the model is set up to accept other starting dates for vehicle technology and fuel shares.

The model calculates energy use, oil use, and carbon emission results for all years between 2000 and 2050 but displays the results only for 2000, 2010, 2020, 2030, 2040, and 2050 on the "Model Results" sheet. (See Figure A.1. Only light vehicle results are shown for a sample case, but heavy vehicle results are also available on this sheet.) If results for intervening years are needed, they can be found in various worksheets.

The model calculates average new car and light truck fuel economy for 2000, 2010, 2020, 2030, 2040, and 2050 on the "Light Vehicle MPG" sheet. (See Figure A.2.) It does not compute the results for intervening years, although these values for each technology can be found on each technology's individual worksheet.

As stated above, assumptions are generally input in 10-year increments, although starting dates may differ from 2000, 2010, 2020, 2030, 2040, and 2050. The model uses linear interpolation to estimate market shares and fuel economy improvements for the years not specifically input on the "Model Input" sheet. Users wanting to input specific vehicle fuel economy or market penetration in specific years not listed on the "Model Input" sheet will have to hard-wire those inputs in the model's vehicle technology sheets. 

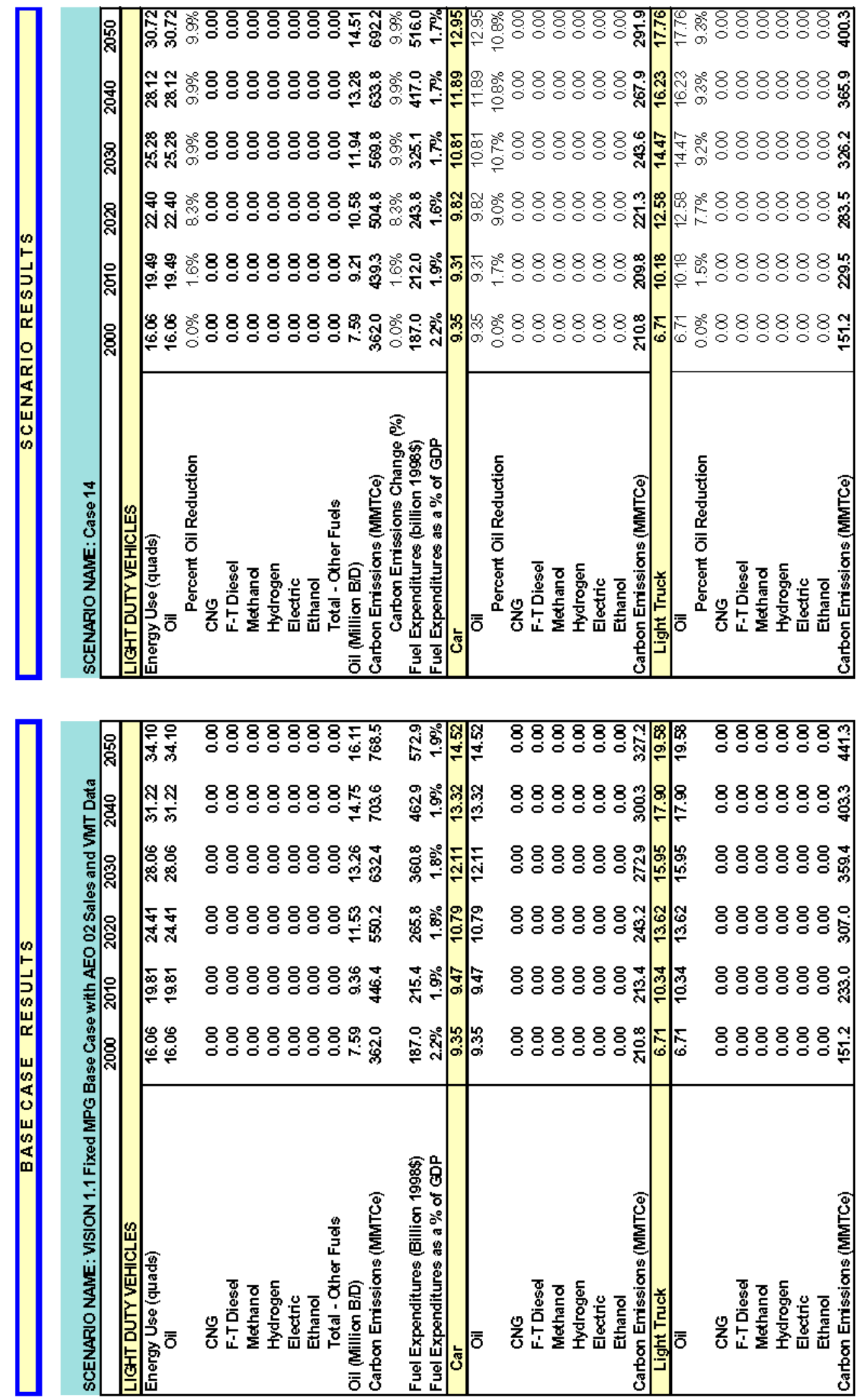

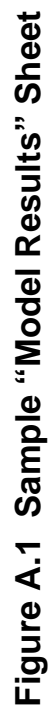




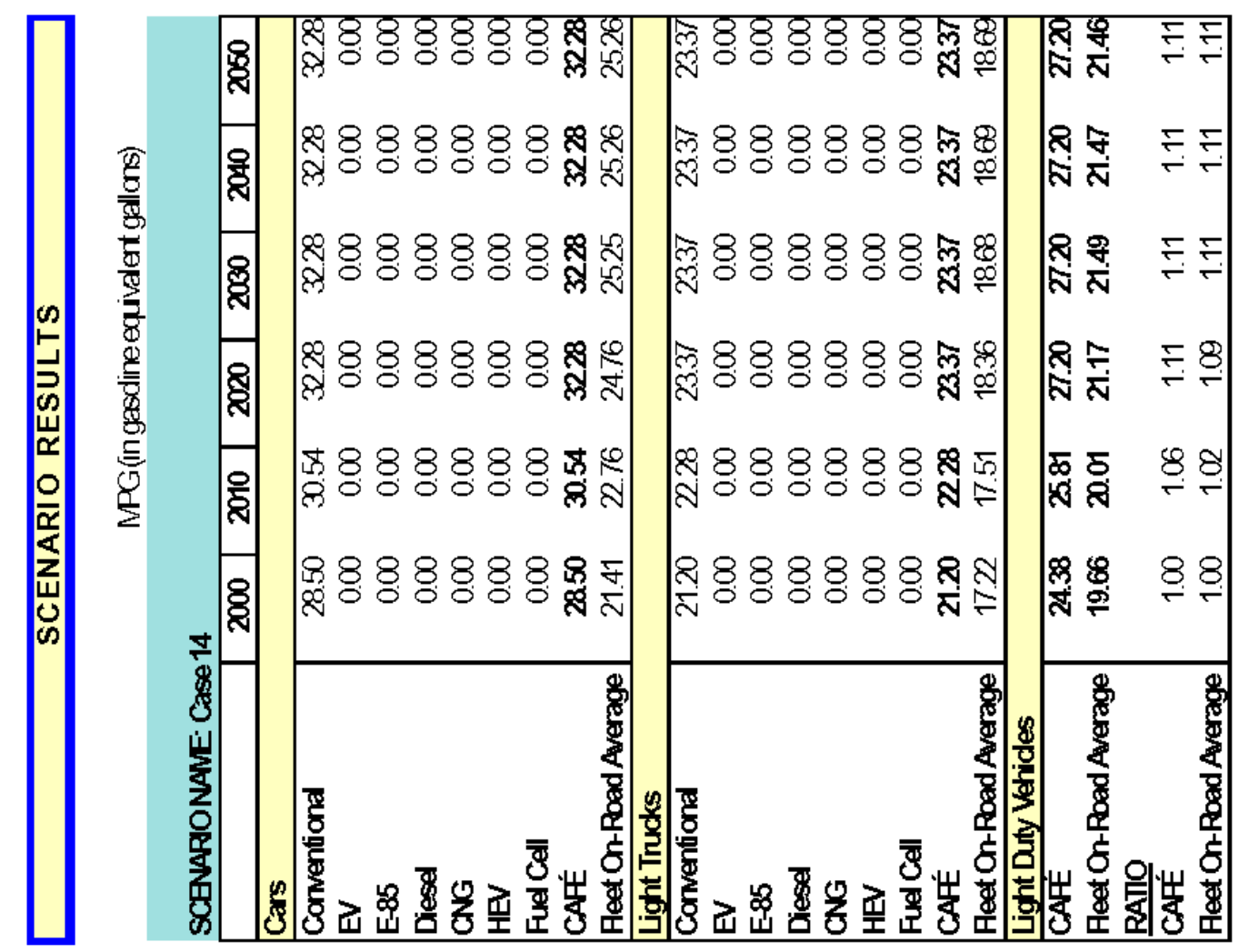

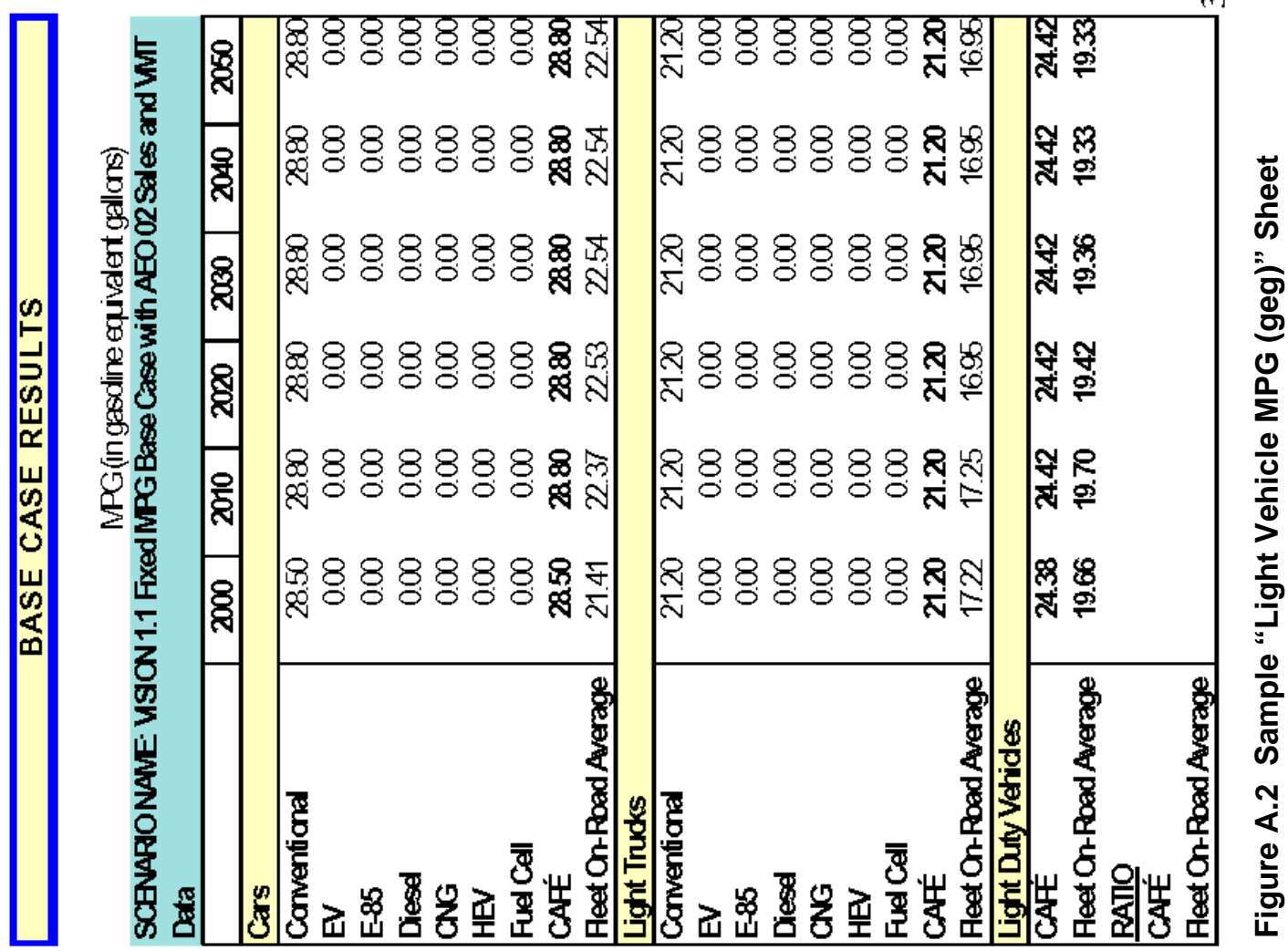


$\Delta$

Users need only to input data to the "Model Input" sheet and review the run results in the "Model Results" sheet. However, there are 35 total sheets in this model. Most are selfexplanatory. 


\section{Appendix B: Updating VISION with Data from a New AEO}

Every year, the VISION Base Case needs to be updated with estimates provided by the latest EIA AEO (and other information sources). Two types of Base Cases have been developed in the past. One assumes (1) no fuel economy improvements between now and 2050 and (2) that all LDV sales are gasoline ICEs. It is called the "Fixed Fuel Economy Base Case." The other matches AEO fuel economy gains and uses AEO's alternative fuel vehicle market penetration assumptions. It is called "the AEO Fuel Economy Base Case."

This appendix describes the procedure for updating only the "Fixed Fuel Economy Base Case" of the model. Examples provided below refer to VISION 2.0, which is a Fixed Fuel Economy Base Case using AEO 2003 data. It is an update of VISION 1.1.2, which used AEO 2002 data. A similar procedure, with a few changes, can be followed to update the "AEO Fuel Economy Base Case" that incorporates AEO sales of new technologies with associated new vehicle fuel economies.

\section{B.1 AEO Projections}

The AEO projections usually include data for one or two historical years. These data are ignored for most of the data fields in favor of known historical values. The sources for the historical data are also described in this appendix. For future years within the AEO projection horizon, the following tables and data are used for updating the "Fixed Fuel Economy Base Case":

1. Table 3: Energy prices by sector and fuel; provides price per million Btu. The prices are converted to 1998 dollars by using implicit price deflators in the most recent Annual Energy Review (AER) published by the EIA. The price deflators are listed in Appendix E of the 2001 AER. The price information is updated in the "Fuel \$ Data" worksheet within VISION.

2. Table 18: Macroeconomic Indicators; provides gross domestic product (GDP) and population. The GDP values are converted to 1992 dollars by using the above-mentioned implicit price deflators. Population data from EIA's Table 18 are not used. Instead, the population data for updating are obtained from the Census Bureau website. These updates are made to the "Population-GDP data" worksheet.

3. Table 45: LDV energy use by mode; provides energy use by cars and light trucks (Class 1 and 2A). These data are used for computing annual VMT for cars and light trucks (Class 1 and 2A). 
4. Table 46: Transportation sector energy use by fuel type within a mode (trillion Btu). These data are copied to the "Energy data" worksheet. Data are useful only if an AEO Base Case is to be developed.

5. Table 48: Light duty vehicle sales. Data from this table and Table 54 (commercial light truck sales) are combined to arrive at car and light truck sales in the "Energy data" worksheet.

6. Table 49: Light duty vehicle stock. Data from this table and Table 55 (commercial light truck stock) are combined to arrive at car and light truck stock.

7. Table 50: Light-duty vehicle miles-per-gallon. The stock average MPG values are used for computing car and light truck (Class 1 and 2A) VMT. The energy consumption projections from Table 45 (in item 3 above) are also used.

8. Table 51: Light-duty vehicle miles of travel. This table provides the combined total VMT for cars and Class 1 and 2A light trucks. The data from Tables 45 and 50 are used with data from this table to derive separate VMT estimates for cars and light trucks.

9. Table 54: Transportation fleet car and truck sales. This table provides Class 2B truck sales (commercial light truck sales in the table). The 2B truck sales data are combined with Class 1 and 2A sales data from Table 48.

10. Table 55: Transportation fleet car and truck stock. This table provides Class 2B truck stock (commercial light truck stock in the table). The 2B truck stock data are combined with Class 1 and 2A sales data from Table 49.

11. Table 56: Transportation fleet car and truck vehicle miles traveled. The data for Class 2B trucks (commercial light truck sales in the table) are added to Class 1 and 2A light truck VMT computed by using data from Tables 45, 50, and 51 .

12. Table 58: Freight transportation energy use. This table provides medium and heavy-duty truck sales, stock, and VMT. It also provides medium truck VMT share by diesel trucks.

These tables are produced by FTAB within the current National Energy Modeling System (NEMS) structure.

\section{B.2 Base Case Update}

The Base Case EXCEL workbook is updated as described below. 


\section{B.2.1 Update Fuel Prices in the "Fuel \$ Data" and "Model Input" Worksheets}

1. Copy historical fuel prices from the latest version of Annual Energy Review. This update is needed only for the most recent two or three years for which data are either revised or released for the first time. The historical data, in constant - or sometimes called real — dollars, are entered in columns $\mathrm{K}$ and $\mathrm{L}$ as dollars per gasoline-equivalent gallon. Convert these prices to 1998 dollars by using implicit price deflators from the Annual Energy Review.

2. Copy projected prices for the future years from Table 3 of the latest AEO in columns B through G. Convert these prices to 1998 dollars by using implicit price deflators from the Annual Energy Review. These prices are then shown in rows 83-90, columns B-D of the "Model Input" worksheet. Until 2002, the AEO projection horizon was 2020. The projection horizon has been moved to 2025 beginning with AEO 2003. The user, through "Model Input" rows 83-90, specifies projected prices for the years 2030, 2040, and 2050. The model estimates the intervening year prices through interpolation. Enter future year fuel prices in 1998 dollars per gasoline-equivalent gallon in rows 83-90 of the "Model Input" worksheet.

3. The AEO 2003 does not provide methanol price projections. The methanol prices for the period 2001-2020 in the "Fuel \$ Data" worksheet are carried forward from an earlier version of the model. They must be updated before any analysis involving methanol can be carried out.

4. The AEO 2003 also does not provide price projections for hydrogen and Fischer-Tropsch diesel. These prices must be specified for all years in rows $87-88$ of the "Model Input" worksheet.

\section{B.2.2 Update Population and GDP Information in the Worksheet "Population-GDP Data"}

1. Copy historical GDP data from the latest version of the Annual Energy Review published by EIA. Convert these data to 1992 dollars by using the implicit price deflators.

2. Copy AEO 2003 GDP projections from Table 18 for years 2002-2025. Convert these projections to 1992 dollars. Use reasonable growth rates for years ending in zero, in consultation with the DOE sponsor, to extrapolate GDP projections through 2050. The model interpolates the GDP growth rates and computes GDP values for the intervening years. For VISION 2.0, the selected GDP growth rates are 2.6\% in 2030, 2.2\% in 2040, and 2\% in 2050 . The AEO 2003 projections use GDP growth rates of $2.8 \%$ in $2005,3.8 \%$ in $2010,2.8 \%$ in $2015,2.7 \%$ in 2020 , and $2.9 \%$ in 2025 . 
3. Update historical population data for the most recent years by using population estimates from the U.S. Census Bureau. The Census web site can be accessed at http://eire.census.gov/popest/data/national/tables/asro/ NA-EST2002-ASRO-01.php. The website also provides estimates of number of persons 16 years of age and older.

4. Use the middle series population projections for all future years through 2050 from the Census website at http://www.census.gov/population/projections/ nation/ summary/np-t1.txt to update future year population. This table provides total population only. Population by age at http://www.census.gov/ population/www/ projections/natsum-T3.html can be used to develop estimates of population age 16 and older.

\section{B.2.3 Update Light Duty Vehicle Sales and Fuel Use Data in the "Energy data" Worksheet}

1. Copy historical car and light truck (up to $10,000 \mathrm{lb}$ GVW) sales data from Ward's Motor Vehicle Facts \& Figures. The data for cars can be found under "Retail Sales" in a table titled "U.S. Retail sales of Passenger Cars by Country of Origin, Market Class, and Purchasing Sector." The data for light trucks are in the next table, titled "U.S. Light Truck Sales by Segment."

2. Sum new car sales and new light truck sales projections in AEO Table 48 and new commercial light truck sales projections in Table 54 to develop total light-duty-vehicle sales projections. Copy these light-duty sales projections in column $\mathrm{F}$ of the "Energy data" worksheet.

3. The model will compute light-duty vehicle sales per thousand persons in column I. Update, if necessary, the future year light-duty-vehicle sales per thousand persons in column I for all years ending in zero beyond the AEO projection horizon. The model will interpolate values for the intervening years.

4. Develop light truck share of total light-duty vehicle sales in AEO projections and copy those shares in column G. Extend these shares to 2050 by providing light truck share values for all years that end in zero. The model will interpolate values for all intervening years. These shares will be used for computing light truck sales if the user specifies "No" in cell A53 of "Model Input."

5. Copy historical fuel use information for the latest available year from ORNL Transportation Energy Data Book from Table 2.4 (Transportation Energy Use by Mode and Fuel Type).

6. Sum light-duty vehicle fuel use by fuel type and commercial light-truck fuel use in AEO Table 46. Convert these data from trillion Btu to quadrillion Btu and copy in columns $\mathrm{N}$ through $\mathrm{U}$. Also, update columns L and M containing 
energy use by cars and light trucks. This step may be skipped for the "Fixed Fuel Economy Base Case."

\section{B.2.4 Update Light-Duty Vehicles, Auto and Light Truck, and Fuel Economy Data in the "Auto-Lt Trk data" Worksheet}

1. Update the historical, EPA-test, auto, and light truck fuel economies in columns $\mathrm{L}$ and $\mathrm{M}$. The historical fuel economy values can be obtained either from the ORNL Transportation Energy Data Book or the National Highway Traffic Safety Administration's website.

2. Select the fixed fuel economy values for the future years in consultation with the DOE sponsor. For the VISION 2.0 update, auto fuel economy was lowered from 28.8 MPG in 2002 to 28.7 MPG in 2003 to 28.6 MPG in 2004 and 28.5 for all subsequent years. The CAFE standard for cars is $27.5 \mathrm{MPG}$, but the fleet average CAFE for cars has exceeded that standard since 1985 . The CAFE standard for light trucks is 20.7 MPG, but will increase to 21.0 MPG in 2005, 21.6 MPG in 2006, and 22.2 MPG in 2007. The fleet average CAFE for light trucks has exceeded the standard for some time, but not by as much as cars. Therefore, the DOE sponsor decided to keep the year 2002 level of 21.2 MPG through 2005 and then increase it to 21.6 MPG in 2006 and 22.2 MPG for all subsequent years.

\section{B.2.5 Develop VMT per Vehicle, Vehicle Stock, and VMT Projections to 2050 for Light-Duty Vehicles Exogenously}

1. From AEO energy use data in Table 45 and fleet average MPG data in Table 50, compute car and light truck (class 2A) VMT. The following formula is used:

$V M T_{v y}=\frac{B t u_{v y} \times M P G_{v y}}{125}$

Where:

$\mathrm{VMT}_{\mathrm{vy}}=\operatorname{VMT}($ billion$)$ for vehicle type $v$ (car or light truck 2A) in year $y$;

$\mathrm{Btu}_{\mathrm{vy}} \quad=$ Energy use, in trillion Btu, by vehicle type $v$ in year $y$;

$\mathrm{MPG}_{\mathrm{vy}}=$ Fuel economy, in miles/gallon, of vehicle $v$ in year $y$; and

$125=$ factor to convert trillion Btu to billion gasoline equivalent gallons (GGE).

2. The sum of the above-computed car and light truck VMT should match the light-duty VMT in Table 51. To ensure this, compute car share of total car and light truck VMT (from item 1, above) and multiply that by the value in 
Table 51. Subtract the car VMT from total LDV VMT in Table 51 to arrive at light truck (class 2A) VMT and then add commercial light truck (class 2B) VMT from Table 56 to arrive at total light truck VMT. Develop year-by-year VMT growth factors for cars and light trucks. Replace the initial year VMT (2000 and 2001 for AEO 2003) with car and 2-axle-4-tire VMT from FHWA's Highway Statistics. Apply VMT growth factors to the latest year for which FHWA VMT data are available to arrive at a first set of car and light truck VMT projections (through the AEO projection period).

3. Add commercial light truck (class $2 \mathrm{~B}$ ) stock in Table 55 to light truck (class 2A) stock in Table 49 to arrive at total light truck stock. Divide the above-developed VMT estimates by AEO car and light truck stock estimates to arrive at VMT per vehicle.

4. Develop graphic representation of VMT per vehicle, and in consultation with the DOE sponsor, extend the VMT per vehicle lines for cars and light trucks to 2050 .

5. Develop growth rates for car and light truck vehicle stock and extend the growth rates to 2050 such that they track the GDP growth rates estimated earlier (see item 2, Section B.2.2). (As all steps under Section B.2.5 are carried out exogenously, these stock growth rates are not input to VISION.)

6. Multiply VMT per vehicle (developed under item 4) by stock (developed under item 5) to arrive at car and light VMT projections to 2050.

7. Develop the final VMT growth factors and update rows 124-133 and 139-148 of the "Model Input" worksheet.

\section{B.2.6 Update the "auto ICE," "It trk ICE," and All Alternative Technology Worksheets for Auto and Light Trucks. (These updates relate to vehicle stock, annual VMT, fleet fuel economy, and annual fuel use.)}

1. Update the worksheets with historical car and light (2-axle-4-tire) truck registration values from the latest highway statistics. Apply correction factors in column AV to match the historical data. The update is needed for the last two years (2000 and 2001) only.

2. The vehicle survival functions within these worksheets are based on past vehicle survival data. The vehicle survival rates have not stayed constant and have also experienced peaks and valleys. The AEO stock estimates are based on a projection methodology that is different from VISION's survival function-based methodology. Consequently, VISION stock projections do not exactly match the AEO stock projections. Correction factors are applied to account for these differences. Develop correction factors in column AV so that when applied to the sums of surviving vehicles, the resulting estimates 
match the projected stock values. Correction factors are also needed post-2025 to match the stock estimates developed under item 5,

Section B.2.5.

3. Link column AV of alternative technology worksheets to "auto ICE" or "lt trk ICE" worksheet as applicable. Copy the formula for estimating vehicle stock during the projection period to all alternative technology worksheets. (Note: All VISION versions after 2.0 will not require this update. This step was required because the method of calculating vehicle stock correction factors in a separate column was inserted the first time in VISION 2.0.)

4. Update the "auto ICE" and "It trk ICE" worksheets with historical car and light truck VMT data from the latest highway statistics. This update will require application of correction factors in column AW. Note that the formula for calculating historical year VMT for years 2000 and 2001 is different in column AA (from that for calculating future year VMT beginning 2002). The historical update is needed for the last two years only.

5. Set the VMT growth method (in cell C111) in the "Model Input" worksheet to 1. Compute VMT per vehicle correction factors for years 2002-2050 in column AW such that the resulting VMT per vehicle for each projection year match the VMT per vehicle estimates developed earlier (under item 4, Section B.2.5).

6. Link the historical VMT per vehicle cells beginning 2000 in "auto ICE" and "It trk ICE" to same cells in alternative technology worksheets as applicable. Copy the total VMT calculation formula from the previous historical year to the newly added historical year in the alternative technology worksheets.

7. Link column AW of alternative technology worksheets to "auto ICE" or "It trk ICE" worksheet as applicable. Copy the formula for estimating VMT per vehicle for projection years to all alternative technology worksheets. (Note: All VISION versions after 2.0 will not require this change. This step was required because the method of calculating VMT per vehicle correction factors in a separate column was inserted the first time in VISION 2.0.)

8. Ensure that the VMT weighted MPG in the "auto ICE" and "lt trk ICE" worksheets match historical fleet average fuel economy in Highway Statistics. Apply correction factors, if needed, in the VMT weighted MPG formula in column AC to achieve this.

9. Copy the VMT weighted MPG correction factor for the last historical year to cell AV4 within the "auto ICE" for cars and "It trk ICE" worksheets for light trucks.

10. Link cell AV4 of respective alternative technology worksheets to the cell AV4 of "auto ICE" and "It trk ICE" worksheets as applicable. The VMT 
weighted MPG formulas in all projection years were corrected to use the correction factor from cell AV4. This step is required once for VISION 2.0 only. All future versions of VISION will automatically have this update.

11. Ensure that the calculated fuel gallons in column $\mathrm{AD}$ for the historical years match the published values in Highway Statistics. Verification is done through correction factors. Past experience has shown that a small factor of 1.0017 is needed for "auto ICE" while no correction factor is needed for "lt trk ICE." Copy correction factor for the last historical year in cell AW4 of "auto ICE" for cars and "It trk ICE" for light trucks. Enter a constant 1 in cell AW4 if no correction is needed.

12. Link cell AW4 of all alternative technology worksheets for cars to cell AW4 of the "auto ICE" worksheet and cell AW4 of all alternative technology worksheets for light trucks to cell AW4 of the "It trk ICE" worksheet. Correct the fuel gallons estimation formula for all projection years within the "auto ICE," other alternative technology worksheets for car, "lt trk ICE," and other alternative technology worksheets for light truck so that the correction factor from cell AW4 can be used. This step is required once when VISION 2.0 is updated and will be carried automatically to future versions of VISION.

\section{B.2.7 Develop Estimates of Medium- and Heavy-Duty Truck Sales, Stock, and VMT Exogenously.}

1. The medium truck segment within VISION is for trucks with gross vehicle weight rating (GVWR) of 10,001-26,000 lb while the heavy truck segment is for trucks with GVWR over 26,000 lb. The sales, stock, and VMT data for these two segments of trucks are compiled in three categories: (1) historical, (2) AEO projections, and (3) extrapolation to 2050.

2. Historical: Ward's Motor Vehicle Facts \& Figures provides retail sales of trucks by GVWR for the latest historical year, and FHWA's highway statistics provide registration and VMT data for the last two historical years for single unit and combination trucks. The 1997 Vehicle Inventory and Use Survey (VIUS) provided stock and VMT split of single unit trucks between medium and heavy trucks. All combination trucks were assumed as heavy trucks.

3. AEO Projections: Table 58 within 2003 AEO's detailed output tables provides projections of medium and heavy truck sales, stock, and VMT.

4. Extrapolation to 2050: Under the Phase 2 of the study entitled North American Transportation Energy Technologies to 2050, regression equations were developed to extend medium and heavy truck sales, stock, and VMT to 2050. These regression equations were used to project growth in sales, stock, and VMT. 
The medium and heavy truck sales are projected by the following equations:

MDT Sales $=-31.9+0.0248 \times$ GDP $-18.59 \times$ Gasoline

HDT Sales $=134+0.026 \times$ GDP $-54 \times$ Gasoline

Where:

GDP $=$ Gross Domestic Product in billions of 1996 chained dollars and

Gasoline $=$ Retail gasoline price in 1996 \$ per gallon .

The medium and heavy truck stocks are projected by the following equations:

MDT Stock $=1584+0.2407 \times$ GDP

HDT Stock $=53.6+0.4554 \times$ GDP

Where GDP $=$ Gross Domestic Product in billions of 1996 chained dollars

The medium and heavy truck VMT are projected by the following equations:

MDT VMT $=10790+3.924 \times$ GDP

HDT VMT $=-12674+18.93 \times$ GDP

Where GDP $=$ Gross Domestic Product in billions of 1996 chained dollars.

The above regression equations are applied to the last projection year of AEO 2003 and all subsequent years. Year-to-year growth factors are computed and applied to the data for the last projection year of AEO 2003.

(Note: The above regression equation may be revised to reflect projections of lower or higher rates of the growth in medium and heavy truck sales, stock, and VMT under future AEOs.)

\section{B.2.8 Update Medium and Heavy Truck Worksheets ("Class 3-6," "Class 3-6 Ng," "Class 3-6 H2," "Class 7\&8," "Class 7\&8 Ng," and “Class 7\&8 H2”).}

a. Update the conventional technology worksheets, "Class 3-6" and "Class 7\&8," with historical sales data from Ward's Motor Vehicle Facts \& Figures and other sales data developed under Section B.2.7. The alternative technology worksheets are automatically updated through links.

b. Update the conventional technology worksheets such that their estimates of medium and heavy truck stock match the above-developed values. As in the case of light-duty vehicles, the vehicle survival procedures within VISION may not produce estimates that match exactly with the historical data, AEO projections, and extrapolated values to 2050. To match VISION's stock estimates with the estimates generated under Section B.2.7, correction factors are developed in column AR. The alternative technology worksheets are automatically updated through links.

c. Update the conventional technology worksheets such that their estimates of medium and heavy truck VMT match the above-developed historical, AEO, and extended values. To match VISION's VMT estimates with the estimates generated under Section B.2.7, correction factors are developed in column AS. The alternative technology worksheets are automatically updated through links. 
d. Update the historical energy consumption (in Btu) by medium and heavy trucks. VISION has been updated earlier through 1999. The Transportation Energy Data Book, Edition 22, provides combined Btu consumption for medium and heavy trucks for 2000. These data were subdivided as medium and heavy truck energy consumption by using Btu shares resulting from the 1997 VIUS data. For 2001, growth in fuel consumption by single unit and combination trucks in FHWA's Highway Statistics was applied to estimate energy use by medium and heavy trucks. Correction factors are applied to the energy consumption estimation formula to have the energy total match with the historical data. The last historical year's correction factor is copied to the cell AS2 of both conventional technology worksheets (i.e., "Class 3-6" and "Class 7\&8"). The energy estimation formulas for all projection years use these factors. The alternative technology worksheets are automatically updated through links. 